\title{
Evolution of fluid flow and carbonate recrystallization rates in deep-sea sediments of the Equatorial Pacific
}

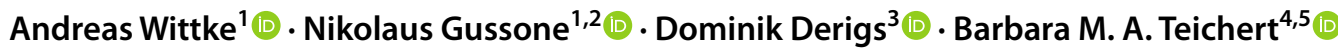

Received: 19 March 2021 / Accepted: 18 October 2021 / Published online: 12 January 2022

(c) The Author(s) 2022, corrected publication 2022

\begin{abstract}
Fluid flow and carbonate recrystallization rates of deep-sea sediments from eight locations in the Equatorial Eastern Pacific were determined by using $\delta^{44 / 40} \mathrm{Ca}$ values of pore water and corresponding sediments. The studied drill sites of IODP Exp. $320 / 321$ are located along a transect of decreasing crustal age and reveal different characteristic pore water depth profiles. The younger sites show an overall isotopic equilibration with the sediment in the upper part of the sedimentary column. In the lower part, the $\delta^{44 / 40} \mathrm{Ca}$ of the pore water increases back to seawater-like values at the sediment/basalt interface, forming a bulge-shaped pore water profile. The magnitude of the $\delta^{44 / 40} \mathrm{Ca}$ pore water bulge decreases with increasing age of the oceanic crust and sediment cover, resulting in seawater-like $\delta^{44 / 40} \mathrm{Ca}$ values throughout the sedimentary column in the oldest Sites U1331 and U1332. These findings indicate a seawater-like fluid input from the underlying crust into the sediment. Thus, after sedimentation, carbonate recrystallization processes start to enrich the pore water in ${ }^{40} \mathrm{Ca}$, and after a time of carbonate recrystallization and cooling of oceanic crust, a flow of seawater-like fluid starts to move upwards through the sedimentary column, enriching the pore water with ${ }^{44} \mathrm{Ca}$. We established a carbonate recrystallization and fluid flow model to quantify these processes. Our determined carbonate recrystallization rates between $0.000013 \mathrm{e}^{(-t / 15.5)}$ and $0.00038 \mathrm{e}^{(-t / 100.5)}$ and fluid flow rates in the range of $0.42-19 \mathrm{~m}^{*} \mathrm{Myr}^{-1}$ indicate that the fluid flow within the investigated sites of IODP Exp. 320/321 depends on the sedimentary composition and location of the specific site, especially the proximity to a recharge or discharge site of a hydrothermal convection cell.
\end{abstract}

Keywords IODP $\cdot$ EXP 320/321 $\cdot$ Pore water $\cdot$ Ca isotopes $\cdot \mathrm{Sr} \cdot$ Diagenesis $\cdot$ Recrystallization $\cdot$ Hydrothermal siphon

\section{Introduction}

Over $70 \%$ of the Earth's surface is covered by water and the largest part of the ocean basin is covered by deep-sea sediments, which consist of up to $70 \%$ of organic carbon

Andreas Wittke

wittke@uni-muenster.de

Nikolaus Gussone

nikolaus.gussone@uni-muenster.de

1 Institut für Mineralogie, Westfälische Wilhelms-Universität Münster, Münster, Germany

2 Wessling GmbH, Altenberge, Germany

3 Physikalisches Institut, Universität zu Köln, Cologne, Germany

4 Institut für Geologie und Paläontologie, Westfälische Wilhelms-Universität Münster, Münster, Germany

5 Agricola Hochschule Bochum, Bochum, Germany depleted clay sediments (Berger 1989; Bowles et al. 2014). Consequently, these sediments are a significant reservoir of the marine realm and diagenetic reactions taking place within, playing an important role in geochemical cycling in the Earth's system. Some of these reactions, for example, microbial redox reactions or abiotic reactions in the fluid phase such as dissolution or precipitation, imprint characteristic patterns of reactants in sedimentary pore water (PW). These processes can be identified by the investigation of pore water profiles of molecule and element concentration and isotopic ratios (e.g., Schulz 2000).

In some deep-sea areas, pore water geochemistry is also controlled by hydrothermal fluxes, affecting the interaction between fluid and sediment or basement. Recently, the hypothesis of hydrothermally driven fluid flow through the oceanic crust has been developed (e.g., Bekins et al. 2007; Fisher et al. 2003; Fisher 2004; Fisher 2005; Villinger et al., 2016; Wheat et al. 2002) suggesting that (inactive) seamounts or bathymetric pits take up and heat up the seawater 
for a period of up to several million years (Villinger and Pichler 2012). Fisher and Wheat (2010) were able to determine an exchange between at least two or more seamounts up to $52 \mathrm{~km}$ apart with a traveling time of the fluid of decades to centuries, correlating to the so-called siphon concept introduced by Fisher (2005). This fluid flow is supposed to be controlled by pressure differences between recharge and discharge site and has been assumed to bypass the sediment (Fisher and Wheat 2010). In some areas, the uptaken fluid does not interact with the oceanic crust as indicated by isotopic measurements of $\delta^{2} \mathrm{H}$ and $\delta^{18} \mathrm{O}$ (Villinger and Pichler 2012) while in other areas it possibly interacts with the minerals of the basaltic crust (Fisher and Wheat 2010). The fluid flow rate through the upper oceanic crust must be high because of the initial increase of the pore water elemental concentrations at the sediment/basalt interface on and near seamounts toward seawater values (Fisher and Wheat 2010). This is owing to frequently inserted "fresh" fluid in the oceanic crust, preventing the equilibration of pore fluid of the sediment and basalt. Therefore, in such systems, the elemental concentration increase toward the sediment/basalt interface depends on the fluid flow rate in the oceanic crust.

The vertical advective flow through the sediment is negligible for a sediment thickness larger than $\sim 400 \mathrm{~m}$ because the permeability of seafloor sediments is lower than the basaltic crust and decreasing permeability with depth (e.g., Spinelli et al. 2004 and literature therein). Advection also depends on lithology, for example, the permeability of pelagic clay is lower underneath $100 \mathrm{~m}$ of sediment column than that of calcareous ooze (Spinelli et al. 2004). Fluid flux rates through sedimentary layers between 10 and around $300 \mathrm{~mm} / \mathrm{a}$ have been reported (Spinelli et al. 2004), but even thin sediment layers of 10-20 m have the potential to stop the vertical advective flow (Fisher and Wheat 2010; Kuhn et al. 2017).

Geochemical pore water profiles of sediment cores from IODP Exp. 320/321 (Equatorial Eastern Pacific) show characteristic features of fluid flow within the oceanic crust and sedimentary cover. Recent research (Voigt et al. 2015) of deep-sea sediment samples of the East Pacific Rise (IODP Exp. 320/321, Sites U1334-U1338) show ${ }^{87} \mathrm{Sr} /{ }^{86} \mathrm{Sr}_{\text {pore water }}$ equal or less radiogenic than the corresponding sediment in the upper half of the sediment core, followed by an increase of ${ }^{87} \mathrm{Sr} /{ }^{86} \mathrm{Sr}_{\text {pore water }}$ back to present-day seawater-like values toward the bottom of the sediment core, while the sediment follows the ${ }^{87} \mathrm{Sr} /{ }^{86} \mathrm{Sr}_{\text {seawater }}$ curve (see McArthur et al. 2001). This observation supports the hypothesis of a recent fluid flux of seawater through the basement, inferred from element concentration profiles (Pälike et al., 2010), because there should be no offset between ${ }^{87} \mathrm{Sr} /{ }^{86} \mathrm{Sr}$ of sediment and pore water without a modern seawater-like fluid input. Other sites in the neighborhood of the East Pacific Rise (ODP Leg 201, Sites 1225 and 1226) show a comparable behavior in $\delta^{34} \mathrm{~S}$ measurements (Böttcher et al., 2006). This behavior was presumed to be caused by a diffusive flow of seawater through the basaltic crust, indicated by $\left[\mathrm{O}_{2}\right],\left[\mathrm{NO}_{3}{ }^{-}\right]$, and $\left[\mathrm{SO}_{4}{ }^{2-}\right]$ measurements (D'Hondt et al., 2004).

An additional tool for investigation of diagenetic reactions in pore water is the $\mathrm{Ca}$ isotope composition (e.g., Fantle and Tipper 2014; Nielsen et al. 2012; Ockert et al. 2013; Teichert et al. 2009), which can be used, for example, for the determination of $\mathrm{CaCO}_{3}$ dissolution (Fantle and DePaolo, 2007; Wittke et al. 2020), $\mathrm{CaCO}_{3}$ precipitation (Teichert et al., 2005; Wittke et al. 2020), ion exchange reactions (Teichert et al. 2009; Ockert et al. 2013), and carbonate recrystallization (e.g., Fantle and DePaolo 2007; Turchyn and DePaolo 2011).

Recently formed carbonate shells of most marine planktic calcifiers have $\delta^{44 / 40} \mathrm{Ca}$ values of about 0.2 to $1.2 \%$ with a mean value of about $0.7 \%$ (Gussone and Heuser 2016), while recent seawater has a value of $\sim 1.88 \%$ o relative to SRM915a (e.g., Fantle and Tipper 2014; Heuser et al. 2016). The difference between the liquid phase and the marine sediments, composed of biogenic carbonates, is caused by the incorporation of light ${ }^{40} \mathrm{Ca}$ in the solid by biological metabolism (e.g., Skulan et al. 1997; Gussone 2006), carbonate precipitation (e.g., Gussone et al. 2003; Lemarchand et al. 2004; Marriott et al. 2004), and to a lesser degree by the preferential absorption of light $\mathrm{Ca}$ isotopes to clay surfaces (Ockert et al., 2013).

Earlier studies (e.g., Fantle and DePaolo 2007) demonstrate that after a given time the carbonate of the sediment of deep-sea plateaus starts to recrystallize, resulting in a conversion of $\delta^{44 / 40} \mathrm{Ca}$ of the pore water and the $\delta^{44 / 40} \mathrm{Ca}$ of the carbonate. On continental slopes and deep-sea plateaus, the $\delta^{44} \mathrm{Ca}$ of the pore water and sediment equilibrate after a given time to a sediment-like value (Bradbury and Turchyn 2018; Fantle and DePaolo 2007; Higgins and Schrag 2012).

To better constrain $\mathrm{CaCO}_{3}$ recrystallization rates and fluid movements within sediment that may be affected by hydrothermal fluid flow, we investigated the $\mathrm{Ca}$ isotope composition of pore water and bulk carbonate sediment of all eight deep-sea sediment cores of IODP Exp. 320/321. Strontium isotope data of the pore water were analyzed for Sites U1331, U1332, and U1333, as those data were not available in the literature to complement the dataset of Voigt et al. (2015).

\section{Material and methods}

\section{Sample material}

The IODP Exp. 320/321 has been carried out in 2008 with the RV Joides Resolution to provide a Cenozoic record of the high productivity zone of the Eastern Equatorial Pacific 
(Fig. 1). To achieve this, drilling of eight sediment cores in the direction of the Pacific plate movement has been accomplished (Pälike et al. 2010).

The investigated sediment cores U1331-U1338 consist mainly of nannofossil ooze, radiolarian nannofossil ooze, radiolarian ooze, nannofossil radiolarian ooze, clay, and porcellanite (Pälike et al., 2010). The $\mathrm{CaCO}_{3}$ content ranges from 1 to 98 wt.\% (see Supplementary information 1; Pälike et al. 2010). Porosity is mostly between 40 and $90 \%$ and decreases with depth (Pälike et al., 2010). The lithology of the sediments strongly varies between calcareous and siliceous layers. Information about the lithology, location, age, and heat flux of the sediment cores is provided in Table 1 and additional details are given in Figs. 53-80 of the cruise report by Pälike et al. (2010).

The pore water was extracted using the so-called wholeround sampling technique onboard the RV Joides Resolution directly after coring, applying pressure within a hydraulic

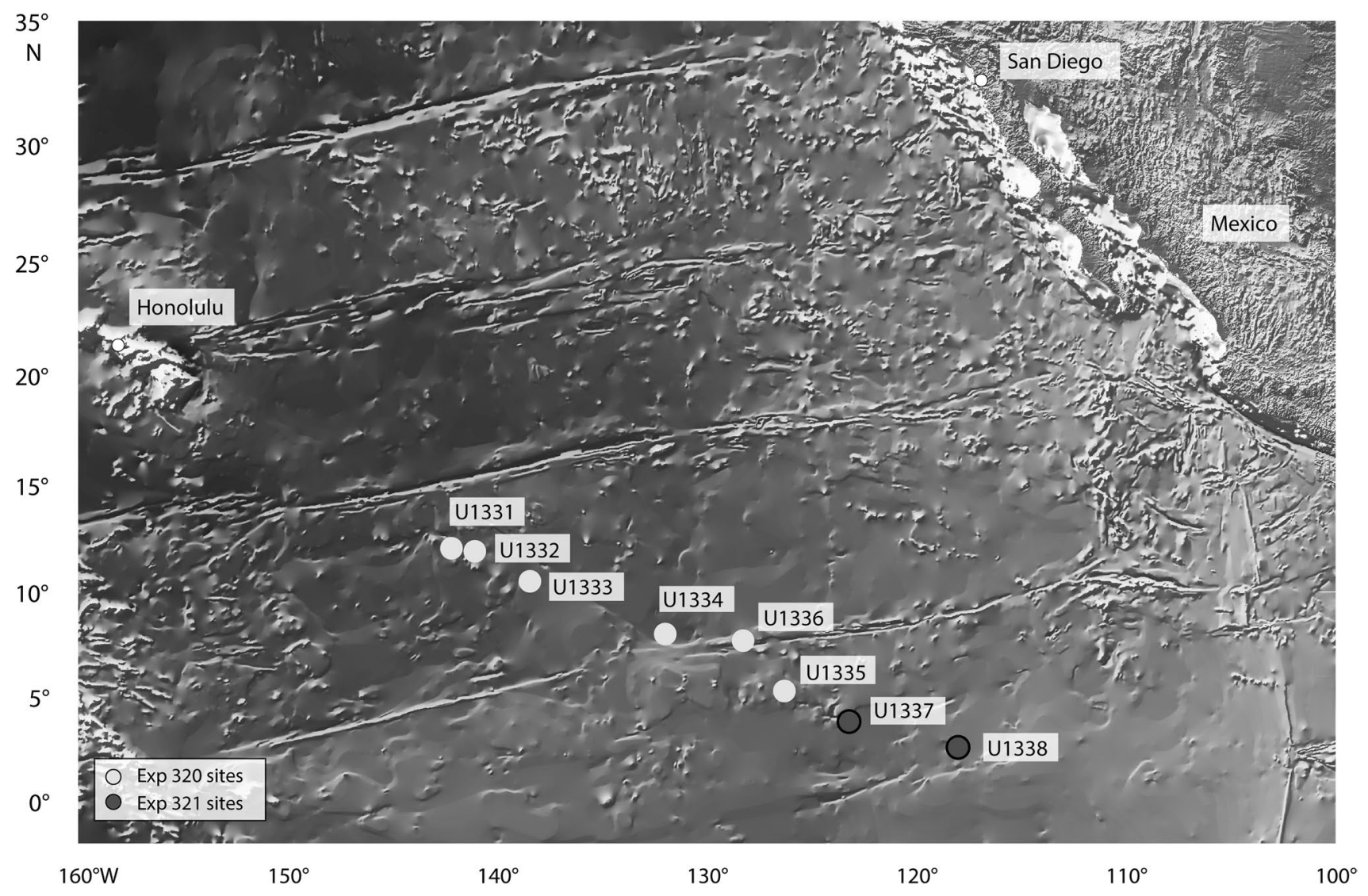

Fig. 1 Locations of drill sites recovered during IODP Expeditions 320/321 to the Equatorial East Pacific in 2008 (modified after iodp.tamu.edu)

Table 1 Location and physical parameters of Sites U1331-U1338 from IODP Exp. 320/321 (Pälike et al., 2010)

\begin{tabular}{|c|c|c|c|c|c|c|}
\hline Site & Location & Water depth (m) & Sediment $(\mathrm{m})$ & $\begin{array}{l}\text { Crustal age } \\
\text { (Ma) }\end{array}$ & $\begin{array}{l}\text { Geothermal } \\
\text { gradient } \\
\left({ }^{\circ} \mathrm{C} \mathrm{km}^{-1}\right)\end{array}$ & $\begin{array}{l}\text { Heat flow } \\
\left(\mathrm{mW} \mathrm{m}^{-2}\right)\end{array}$ \\
\hline U1331A & $12^{\circ} 04.08844^{\prime} \mathrm{N}, 142^{\circ} 09.6961^{\prime} \mathrm{W}$ & 5120 & 190 & 53 & 13.4 & 10.3 \\
\hline U1332A & $11^{\circ} 54.7095^{\prime} \mathrm{N}, 141^{\circ} 02.7428^{\prime} \mathrm{W}$ & 4917 & 152 & 56 & 75.0 & 70.7 \\
\hline U1333A & $10^{\circ} 30.9953^{`} \mathrm{~N}, 138^{\circ} 25.1728^{\prime} \mathrm{W}$ & 4858 & 184 & 46 & 37.9 & 42.3 \\
\hline U1334A & $7^{\circ} 59.9980^{`} \mathrm{~N}, 131^{\circ} 58.3937^{`} \mathrm{~W}$ & 4793 & 285 & 38 & 33.0 & 31.6 \\
\hline U1335A & $5^{\circ} 18.7341^{\circ} \mathrm{N}, 126^{\circ} 16.9949^{\circ} \mathrm{W}$ & 4333 & 421 & 26 & 7.4 & 6.9 \\
\hline U1336B & $7^{\circ} 42.05999^{`} \mathrm{~N}, 128^{\circ} 15.2533^{`} \mathrm{~W}$ & 4292 & 174 & 32 & $\mathrm{n} / \mathrm{a}$ & $\mathrm{n} / \mathrm{a}$ \\
\hline U1337A & $3^{\circ} 50.0065^{\circ} \mathrm{N}, 123^{\circ} 12.3558^{\circ} \mathrm{W}$ & 4465 & 450 & 24 & 32.4 & 28.4 \\
\hline U1338A & $2^{\circ} 30.4685^{\circ} \mathrm{N}, 117^{\circ} 58.1623^{\circ} \mathrm{W}$ & 4204 & 410 & 18 & 34.4 & 33.6 \\
\hline
\end{tabular}


press to the sediment segment or by the Rhizon sampling technique, using vacuum to gather the pore water. In both techniques, the pore water is filtered and released into syringes. It was then transferred into pre-cleaned HDPE screw-top vials and acidified with $\mathrm{HCl}$. Both techniques are comparable at the present-day reproducibility (Wittke et al., 2020).

\section{Sample preparation}

\section{Pore water $\mathrm{Ca}$ and $\mathrm{Sr}$ chemistry}

For $\mathrm{Ca}$ isotope analyses, aliquots of the pore water samples were spiked with a ${ }^{42} \mathrm{Ca}-{ }^{43} \mathrm{Ca}$ double spike following the method of Gussone et al. (2011) to correct for fractionation during column chemistry and isotope fractionation in the ion source of the TIMS during isotope analysis (Russel et al. 1978). Calcium was separated from other elements, in particular $\mathrm{K}^{+}$because of the isobaric interference of ${ }^{40} \mathrm{~K}$ on ${ }^{40} \mathrm{Ca}$, with an ion chromatography column using the method of Ockert et al. (2013). We used pre-cleaned Teflon columns filled with $1.8 \mathrm{~N} \mathrm{HCl}$ conditioned MCI Gel CK08P resin. Samples were loaded in $1.8 \mathrm{~N} \mathrm{HCl}$ onto the columns. The purified $\mathrm{Ca}$ was collected in Teflon vials, evaporated, and finally recovered in $6 \mathrm{~N} \mathrm{HCl}$.

For Sr purification, conditioned Teflon columns filled with precleaned and conditioned $\mathrm{Sr}-\mathrm{Spec}$ resin with $3 \mathrm{~N}$ $\mathrm{HNO}_{3}$ have been used following the method in Teichert et al. (2005). Samples were loaded in $3 \mathrm{~N} \mathrm{HNO}_{3}$ and the matrix has been washed off, while the $\mathrm{Sr}$ was eluted with $\mathrm{H}_{2} \mathrm{O}$. The purified $\mathrm{Sr}$ was evaporated and recovered in $6 \mathrm{~N} \mathrm{HCl}$.

The elemental concentration measurements of $\mathrm{Ca}^{2+}, \mathrm{Li}^{+}$, and $\mathrm{Sr}^{2+}$ were performed onboard the RV Joides Resolution using an ICP-OES (Pälike et al. 2010).

\section{Sediment}

The dry sediment residue left after pore water extraction, the so-called squeeze cake, was cut and sealed onboard directly after the pore water was extracted. For Ca isotope analysis, an aliquot of each of these squeeze cakes has been crushed. Approximately $1 \mathrm{mg}$ of the sample powder was leached in $1 \mathrm{ml} 2.5 \mathrm{~N} \mathrm{CH}_{3} \mathrm{COOH}$ at ambient temperature, and to obtain the dissolved $\mathrm{CaCO}_{3}$ fraction, it was separated from the remaining solid (silicate) phase by centrifuging. Both parts were dried and weighed to determine the carbonate content of the sample. The carbonate fraction was re-dissolved in $2.5 \mathrm{~N} \mathrm{HCl}$, spiked with the ${ }^{42} \mathrm{Ca} /{ }^{43} \mathrm{Ca}$ double spike and dried down at $60{ }^{\circ} \mathrm{C}$ for $3 \mathrm{~h}$. Because of the pureness of the $\mathrm{CaCO}_{3}$ leachates, no Ca clean-up by column chemistry was required before mass spectrometry.

\section{Basalt}

The digestion of basalt largely follows the method described in Magna et al. (2015) and Gussone et al. (2020) with the addition of an acetic acid leaching step. About $100 \mathrm{mg}$ of basalt powder has been leached with $1 \mathrm{~N} \mathrm{CH}_{3} \mathrm{COOH}$ for $24 \mathrm{~h}$ at ambient temperature. The dissolved carbonate fraction was separated from the silicate residue by centrifuging. The silicate fraction was dissolved in $3 \mathrm{ml}$ conc. $\mathrm{HF}+\mathrm{HNO}_{3}(5: 1)$ solution and placed in Teflon screw-top vials with closed lids at $80^{\circ} \mathrm{C}$ on the hotplate until total dissolution, then the digest was dried down. Next, the sample material was dissolved in $6 \mathrm{~N} \mathrm{HCl}$ and heated at $120^{\circ} \mathrm{C}$ overnight and dried down afterward again. The silicate and carbonate fractions were redissolved in $2.5 \mathrm{~N} \mathrm{HCl}$ and purified as described in the section "Mass spectrometry" for $\mathrm{Ca}$ and $\mathrm{Sr}$ isotope measurement.

\section{Mass spectrometry}

\section{Ca isotopes}

The samples were loaded on Re single filaments using a sandwich method loading $0.5 \mu \mathrm{l}$ and $1 \mu \mathrm{l}$ of $\mathrm{TaF}_{5}$ solution as an activator before and after $1 \mu \mathrm{l}$ of the sample was loaded (e.g., Gussone et al., 2018). Measurements were performed on a Thermo Fisher Scientific Triton at the Institut für Mineralogie at the Westfälische Wilhelms-Universität Münster, Germany. The ${ }^{44} \mathrm{Ca} /{ }^{40} \mathrm{Ca}$ was calculated based on measurements as well as ${ }^{40} \mathrm{Ca} /{ }^{43} \mathrm{Ca}$ and ${ }^{44} \mathrm{Ca} /{ }^{43} \mathrm{Ca}$. Potential ${ }^{40} \mathrm{~K}$ interference on mass ${ }^{40} \mathrm{Ca}$ was corrected by monitoring ${ }^{41} \mathrm{~K}$ (Heuser et al. 2002). The $\delta^{44 / 40} \mathrm{Ca}$ is calculated using Eq. 1 and as a reference standard SRM915a has been used. The average external error of all sample measurements (2 SD) is about $0.07 \%$. The analytical error is given as $2 \mathrm{SE}$ of the replicate measurements. Ten measurements of an IAPSO (seawater) standard yielded a $\delta^{44 / 40} \mathrm{Ca}$ value of $1.84( \pm 0.03$ $2 \mathrm{SE}$ ), which is in accordance with literature values (e.g., Fantle and Tipper 2014; Heuser et al. 2016).

$\delta^{44 / 40} C a(\% o)=\left(\frac{\left(\frac{{ }^{44} \mathrm{Ca}}{{ }^{40} \mathrm{Ca}}\right)_{\text {sample }}}{\left(\frac{{ }^{44} \mathrm{Ca}}{{ }^{40} \mathrm{Ca}}\right)_{\text {standard }}}-1\right) \times 1000$

\section{Sr isotopes}

Strontium ( $500 \mathrm{ng})$ was loaded on single W-filament using a sandwich method, with $1 \mu \mathrm{TaF}_{5}$ solution as activator loaded before and after the sample. The samples were measured with a Thermo Scientific Triton at the Institut für Mineralogie at the Westfälische Wilhelms-Universität 
Münster, Germany. Samples were corrected by using NBS987. Ten analyses of NBS987 yielded an ${ }^{87} \mathrm{Sr} /{ }^{86} \mathrm{Sr}$ of $0.710278 \pm 1.3 \mathrm{E}-5$ ( $2 \mathrm{SD}$ ). The analytical error for the individual sample measurement is given as $1 \mathrm{SE}$.

\section{Results}

\section{Calcium}

The $\delta^{44 / 40} \mathrm{Ca}$ values of pore waters $\left(\delta^{44 / 40} \mathrm{Ca}\right.$ pw from all sites range from 0.26 to $1.97 \%$ and those of the bulk carbonate $\left(\delta^{44 / 40} \mathrm{Ca}_{\mathrm{CC}}\right)$ of the sediment (derived from the squeeze cakes) from 0.19 to $1.10 \%$ (Fig. 2, Supplementary information 1). The individual sites show different patterns in their pore water depth profile. The $\delta^{44 / 40} \mathrm{Ca}_{\mathrm{pw}}$ of Site U1331 (Fig. 2a) starts with a value of $1.81 \%$ at the top of the sediment column, followed by a small decrease and a slight increase above the mean seawater value of $\sim 1.88 \%$ o relative to SRM915a (e.g., Fantle and Tipper 2014; Heuser et al. 2016), with values between 1.92 and $1.97 \%$ in a depth of around $12 \mathrm{~m}$ and $32 \mathrm{~m}$. The excursion between 8 and $32 \mathrm{~m}$ is in the depth of a turbidite (Pälike et al., 2010), where younger carbonate-rich sediment formed above the calcite compensation depth (CCD) was rapidly transported below the CCD. A correlating decreasing value of the $\delta^{44 / 40} \mathrm{Ca}_{\mathrm{CC}}$ is observed, starting from a relatively high value of $1.1 \%$ o at around $3 \mathrm{~m}$ down to a value of $0.66 \%$ near the basement.
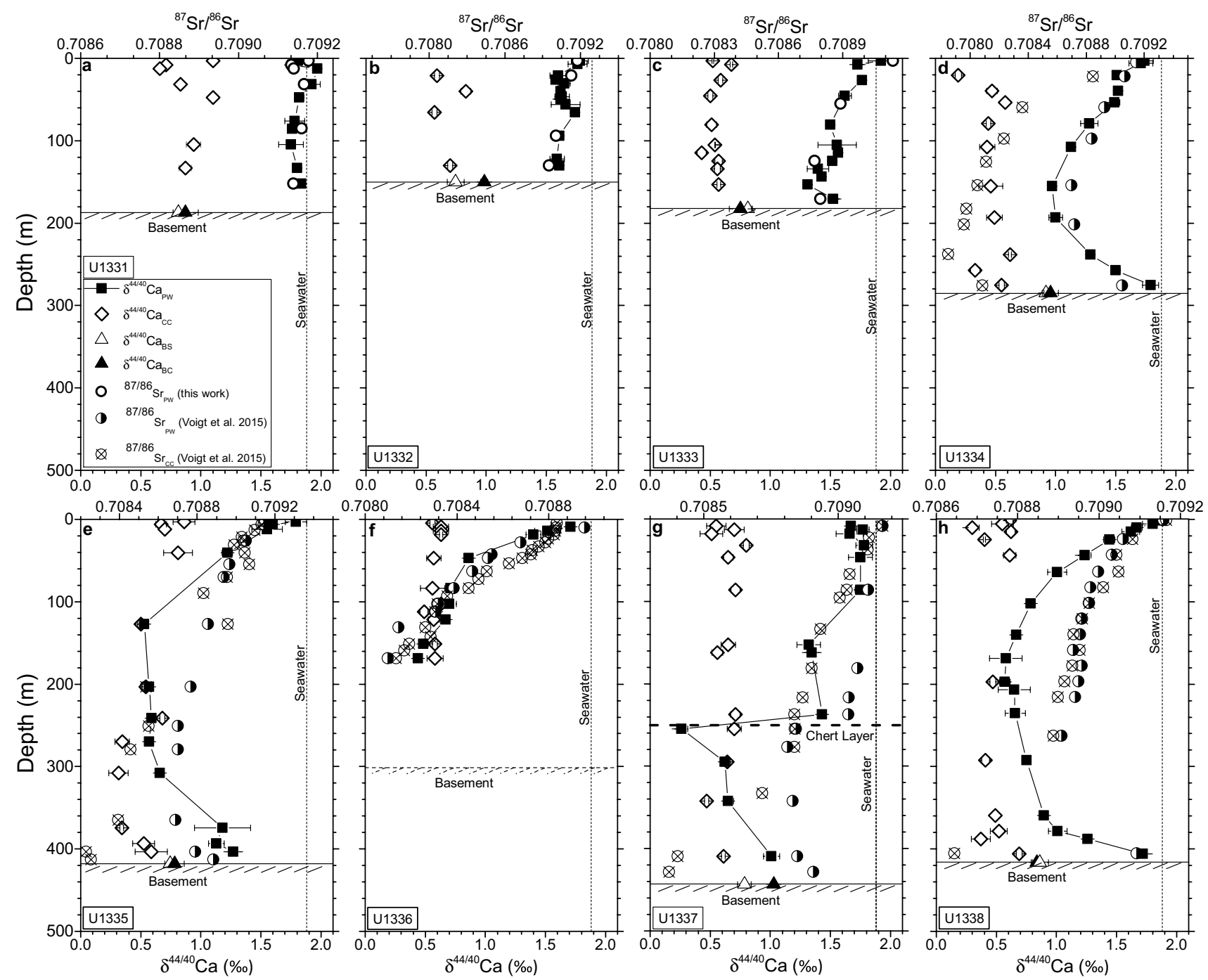

Fig. $2 \delta^{44 / 40} \mathrm{Ca}$ and ${ }^{87} \mathrm{Sr} /{ }^{86} \mathrm{Sr}$ profiles of pore water (PW), sediment carbonate (CC), basalt (BS), and the carbonate cement of the basaltic pore spaces (BC) of IODP Sites U1331-U1338. ${ }^{87} \mathrm{Sr} /{ }^{86} \mathrm{Sr}$ values of Sites U1334-U1338 are from Voigt et al. (2015). Depth is given as $\mathrm{CSF}=$ core depth below sea floor. The dashed vertical line represents

the modern average seawater value of $\delta^{44 / 40} \mathrm{Ca}$ (e.g., Fantle and Tipper 2014; Heuser et al. 2016). The solid horizontal line represents the depth of the oceanic crust of the specific sites and the dashed horizontal line in subplot $g$ of Site U1337 represents the position of the chert layer (Pälike et al. 2010) 
The $\delta^{44 / 40} \mathrm{Ca}$ pore water profile of Site U1332 (Fig. 2b) starts with a near seawater value of $1.78 \%$ at the sediment/ seawater interface, followed by a decrease to a value of $1.58 \%$ at a depth of around $25 \mathrm{~m}$. Within error, this value remains constant down to the basement except for one sample at $65 \mathrm{~m}$ with a value of $1.74 \%$. The bulk carbonate of the sediment ranges between 0.57 and $0.83 \%$ at this site.

Site U1333 (Fig. 2c) starts with a $\delta^{44 / 40} \mathrm{Ca}_{\mathrm{pw}}$ value $(1.92 \%$ o almost equal to recent seawater and decreases to a value of $1.31 \%$ at a depth of $153 \mathrm{~m}$ followed by an increase to $1.52 \%$ at the sediment/basement interface. The $\delta^{44 / 40} \mathrm{Ca}_{\mathrm{CC}}$ ranges between 0.43 and $0.59 \%$.

Site U1334 (Fig. 2d) has $\delta^{44 / 40} \mathrm{Ca}$ pore water values of between 1.71 and $1.74 \%$ in the upper $6 \mathrm{~m}$, followed by a decrease to a value of $0.97 \%$ at a depth of around $155 \mathrm{~m}$ in the middle of the sediment column. In the lower part of this site, the $\delta^{44 / 40} \mathrm{Ca}$ pore water values increase back toward seawater-like values of $1.79 \%$. The $\delta^{44 / 40} \mathrm{Ca}$ of the sediments carbonate phase starts at a low value of $0.19 \%$ at around $20 \mathrm{~m}$, increases within the following $20 \mathrm{~m}$ to a value of $0.47 \%$ and remains in a range between 0.33 and $0.62 \%$ in the lower part of the core.

Sites U1335 (Fig. 2e) and U1338 (Fig. 2h) show similar behavior for Ca isotope systematics. Both start with a seawater-like value of $1.79 \%$ and $1.83 \%$, respectively, at the top layer and decrease within the first $120 \mathrm{~m}$ (Site U1335) and $160 \mathrm{~m}$ (Site U1338) of the sites to sediment-like pore water values of $0.53 \%$ and $0.57 \%$ and remain in this range for around $200 \mathrm{~m}$. In the lower part of the cores, the $\delta^{44 / 40} \mathrm{Ca}$ pw increases toward seawater values at the basement/sediment interface. The sediment $\delta^{44 / 40} \mathrm{Ca}_{\mathrm{CC}}$ values of Sites U1335 and $\mathrm{U} 1338$ range from 0.31 to $0.86 \%$ and between 0.3 and $0.69 \%$, respectively. In both sediment columns, an increase in the $\delta^{44 / 40} \mathrm{Ca}$ of the bulk carbonate sediment in the lowest sample is indicated, which is however within the analytical uncertainty.

The upper part of the sediment column of Site U1336 (Fig. 2f) shows, like Sites U1335 and U1338, a rapid decrease of the pore water calcium isotope values downwards, reaching sediment-like values of $0.44 \%$ at a depth of approximately $170 \mathrm{~m}$. Because of the shipboard sampling strategy, pore water was not sampled in the lower part at this site. The bulk carbonate values range between 0.49 and $0.63 \%$.

The pore water $8^{44 / 40} \mathrm{Ca}$ of Site U1337 (Fig. $2 \mathrm{~g}$ ) shows a clear separation into two different units. In the upper $85 \mathrm{~m}$ $\delta^{44 / 40} \mathrm{Ca}$ values are around seawater values, with a slight decrease to values of between 1.32 and $1.34 \%$ in a depth of 152 and $162 \mathrm{~m}$, and a small increase to $1.43 \%$ at a depth of $237 \mathrm{~m}$. This small increase is followed by a rapid decrease to a value of $0.26 \%$ within $17 \mathrm{~m}$ at the depth of a chert layer. In this depth, the $\delta^{44 / 40} \mathrm{Ca}$ is even below the corresponding sediment value of $0.70 \%$. The $\delta^{44 / 40} \mathrm{Ca}_{\mathrm{pw}}$ in the lower section increases with depth to a value of $1.01 \%$ at the basalt/sediment interface, while the sediment $\mathrm{Ca}$ isotope ratio of the whole sediment column varies between 0.47 and $0.80 \%$, describing a small bulge shape underneath the chert layer, while the values remain almost similar in the upper part of the sediment core.

The $\delta^{44 / 40} \mathrm{Ca}$ values of the basaltic basement of all measured sites range between 0.75 and $0.92 \%$, while the carbonate precipitated in the pore space of the basalt ranges from 0.75 to $1.03 \%$ o (see Supplementary information 1). Corresponding silicate and carbonate values of the basalt of each site are mostly overlapping within analytical uncertainties (Fig. 2).

\section{Strontium}

The ${ }^{87} \mathrm{Sr} /{ }^{86} \mathrm{Sr}$ of the pore waters of Site U1331 ranges between 0.709139 and 0.709179 , showing a $\mathrm{Sr}$ isotopic composition similar to recent seawater through the whole sedimentary column with a noteworthy change to less radiogenic values in the depth of the turbidite layer (Supplementary information 1, Figs. 2a and 3a). At Site U1332 (Figs. 2b and $3 b)$, the ${ }^{87} \mathrm{Sr} /{ }^{86} \mathrm{Sr}$ ranges between 0.708951 and 0.709176 , thus starting at a recent seawater value at the top of the sediment core with a slight shift to less radiogenic values, i.e., toward ancient Sr seawater values (McArthur et al. 2001) with increasing depth. With decreasing crustal age, the $\mathrm{Sr}$ isotope profile of Site U1333 (Figs. 2c and 3c) continues the evolution of the slope toward the ancient seawater curve and ranges between 0.708770 and 0.709136 .

The ${ }^{87} \mathrm{Sr} /{ }^{86} \mathrm{Sr}$ of the carbonate in the pore space of the basalts ranges between 0.7073383 and 0.7087182 (Supplementary information 1 ).

\section{Discussion}

In the upper parts of the younger Sites U1335 and U1338, the $\delta^{44 / 40} \mathrm{Ca}_{\mathrm{pw}}$ values converge with the isotopic composition of the solid toward depth, resembling typical $\delta^{44 / 40} \mathrm{Ca}$ pw and ${ }^{87} \mathrm{Sr} /{ }^{86} \mathrm{Sr}$ profiles (Bradbury and Turchyn 2018; Teichert et al. 2009; Fantle and DePaolo 2007, 2006; Higgins and Schrag 2012) that show a convergence of pore water and solid toward the basement. In contrast, the investigated sites of IODP Exp. 320/321 show a different trend in the lower sediment section, with increasing $\delta^{44 / 40} \mathrm{Ca}_{\mathrm{pw}}$, reaching seawater-like values at the basement. This pattern of $\delta^{44 / 40} \mathrm{Ca}_{\mathrm{pw}}$ profiles resembles trends of ${ }^{87} \mathrm{Sr} /{ }^{86} \mathrm{Sr}$ (Voigt et al. 2015; Fig. 2) and element concentrations of $\mathrm{Li}^{+}$and $\mathrm{Sr}^{2+}$ of these sites (Pälike et al., 2010; Fig. 4). The $\mathrm{Sr}^{2+}$ pattern has been assumed to be an effect of carbonate diagenesis and recrystallization, where $\mathrm{Sr}^{2+}$ is released to the pore fluid (Pälike et al., 2010). The $\mathrm{Li}^{+}$pattern was interpreted as diagenetic 

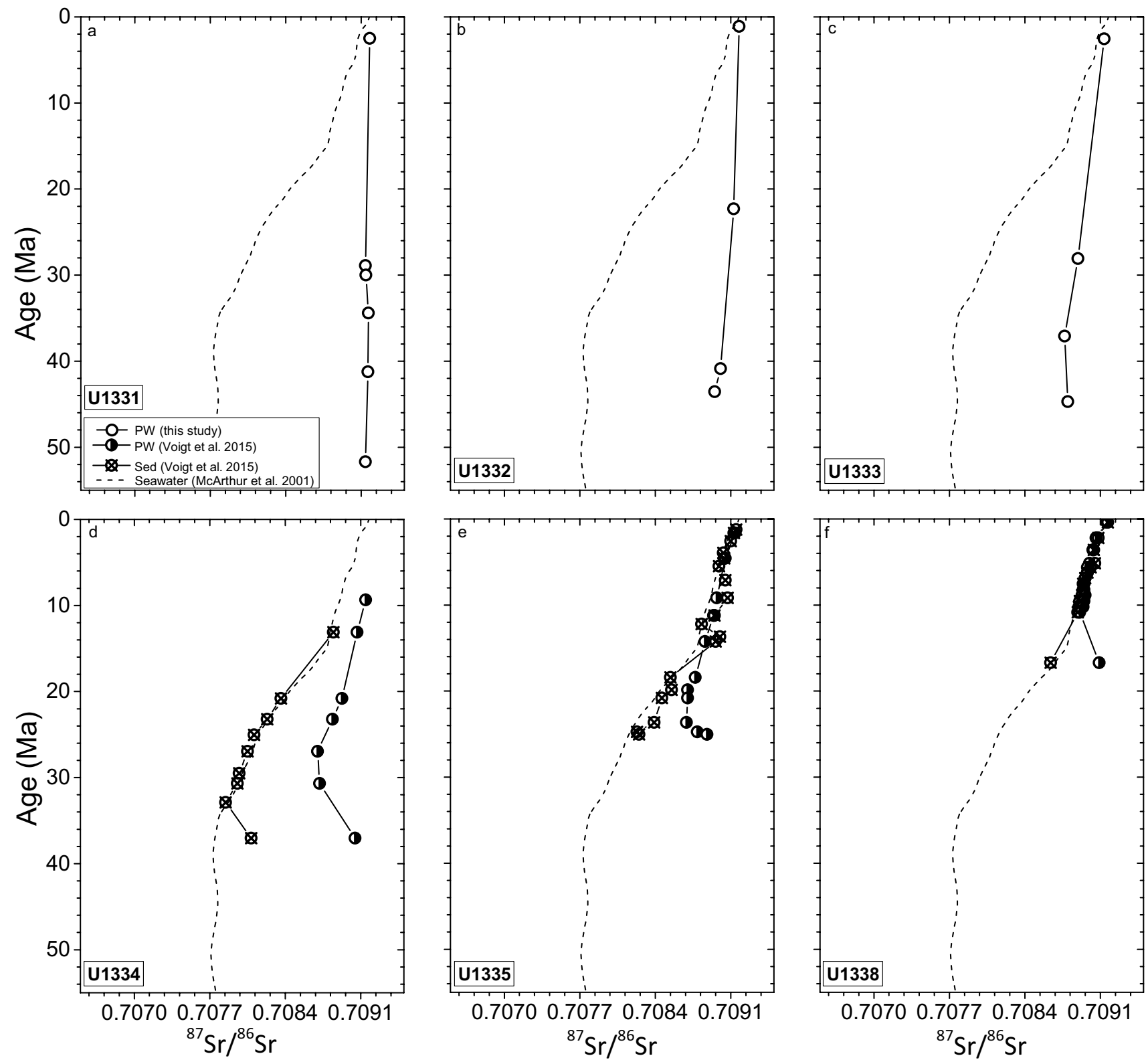

Fig. $3{ }^{87} \mathrm{Sr} /{ }^{86} \mathrm{Sr}$ of the pore water compared to the paleo-seawater curve (McArthur et al. 2001) and/or sediment of Sites U1331-U1338. Sr isotope ratios of Sites U1334 to U1338 are taken from Voigt et al. (2015)

reactions in the sediments, where $\mathrm{Li}$ is consumed by potential clay diagenesis at low temperatures (Pälike et al., 2010). The extent of these bulges is negatively related to the age of the underlying oceanic crust and positively related to sediment thickness. This is strongly pronounced in the younger sites, which have a thicker sediment cover, while the bulge is almost absent at the oldest Sites U1332 and U1331, which have thinner sediment covers. One possibility to explain these findings is the previously mentioned "siphon concept" (Fisher 2005). Owing to this concept, where seawater is taken up at a recharge site and released at a discharge site such as seamounts or hydrothermal pits, it is known that diffusive exchange can occur between the oceanic crust and the lower part of the overlying sediment (e.g., Fisher and Wheat 2010; Voigt et al. 2015), where the average marine sediment has lower permeability than the upper oceanic crust (Fisher et al. 2008; Spinelli et al. 2004).

The observed increase in ${ }^{87} \mathrm{Sr} /{ }^{86} \mathrm{Sr}$ (Voigt et al. 2015 and this work; Figs. 2 and 3 ) and $\delta^{44 / 40} \mathrm{Ca}$ of the pore water toward modern seawater-like values (Fig. 2) approaching the interface of the sediment and oceanic crust is associated with a divergence of pore water and the sediment isotopic compositions. This is consistent with a scenario where an input of a seawater-like fluid from the basement takes place. 

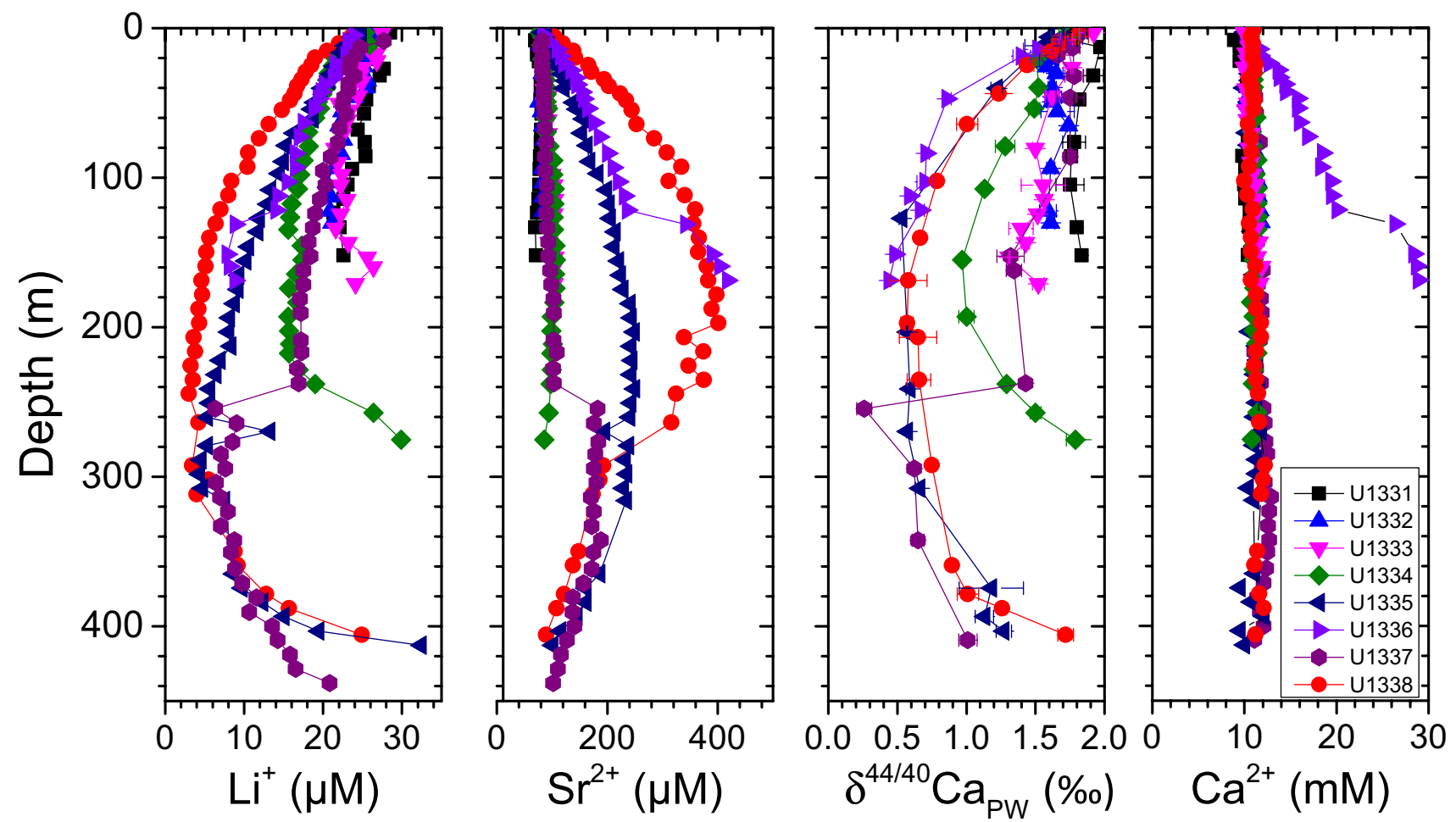

Fig. $4 \mathrm{Li}^{+}, \mathrm{Sr}^{2+}$, and $\mathrm{Ca}^{2+}$ elemental concentration profile (Pälike et al., 2010) compared to $\delta^{44 / 40} \mathrm{Ca}_{\mathrm{pw}}$ (this work)

For $\delta^{44 / 40} \mathrm{Ca}$, this behavior is caused by the fact that the sediment has low $\delta^{44 / 40} \mathrm{Ca}$ values compared to seawater and during carbonate recrystallization $\delta^{44 / 40} \mathrm{Ca}_{\mathrm{pw}}$ and $\delta^{44 / 40} \mathrm{Ca}_{\mathrm{CC}}$ converge, whereas ${ }^{87} \mathrm{Sr} /{ }^{86} \mathrm{Sr}$ of the carbonate sediments are less radiogenic than present seawater (e.g., McArthur et al. 2001; Fig. 3). The $\delta^{44 / 40} \mathrm{Ca}$ of the bulk carbonate sediments agrees overall with reconstructions of ancient $\delta^{44 / 40} \mathrm{Ca}$ of the seawater (Griffith et al. 2011; Heuser et al. 2005; Pabich et al. 2014; Sime et al. 2007; Fig. 5) except for Site U1331 where an enrichment in ${ }^{44} \mathrm{Ca}$ can be seen in sediments older than $\sim 40 \mathrm{Ma}$. Thus, the increase in $\delta^{44 / 40} \mathrm{Ca}_{\mathrm{pw}}$ of the lower parts back to seawater-like values in the younger sites has to be a result of a seawater-like fluid coming from the oceanic crust because in the middle part of, e.g., Sites U1335 and U1338, the $\delta^{44 / 40} \mathrm{Ca}_{\mathrm{pw}}$ equilibrates with sediment values. The flattening of the $\delta^{44 / 40} \mathrm{Ca}_{\mathrm{pw}}$ profile with increasing age of the sites may suggest that this seawater-like fluid flushes the whole sedimentary column in these sites and exits at the top of it back to the ocean. Also, an indicator for a potential high fluid flux through the whole sedimentary column could be the pore water profiles of Sites U1331, U1332, and U1333 and the upper part of Site U1337, which show no correlation with the Sr isotopic seawater curve over time (McArthur et al. 2001; Fig. 3).

Some investigated sites, namely, U1334, U1335, and U1338, show an increase of the $\delta^{44 / 40} \mathrm{Ca}_{\mathrm{CC}}$ in the lowest part of the sediment cover, which could be interpreted as an enrichment of the sediment in ${ }^{44} \mathrm{Ca}$ owing to carbonate recrystallization during ongoing seawater input. However, this increase is in the order of $0.1-0.2 \%$ and therefore close to analytical uncertainties. Nevertheless, these data may indicate that carbonate recrystallization at high fluid/rock ratios may shift the $\delta^{44 / 40} \mathrm{Ca}$ of the carbonate over time, as described for shallow water areas owing to high porosity and fluid flow because of low sediment compaction (e.g., Ahm et al. 2018, 2019; Higgins et al 2018), while in deepsea samples the higher porosity is induced by hydrothermal fluid exchange between the sediment and basaltic basement.

The carbonate leachates of the basaltic basement reveal for Sites U1334, U1335, and U1337 ${ }^{87} \mathrm{Sr} /{ }^{86} \mathrm{Sr}$ ratios close to the seawater curve (Fig. 6) with an approximate age offset of about 4 Myr. Site U1332 and Site U1333 have a similar $\mathrm{Sr}$ isotope signature, indicating a similar age of carbonate formation (16-21 Ma), however, offset by 30 and $34 \mathrm{Myr}$ to the crust formation. This is likely related to a low biocarbonate production at the time of basaltic crust formation and early subsidence of these sites below the CCD. The intra-basalt carbonates of Sites U1332-U1337, except Site $\mathrm{U} 1334$, seem to be precipitated in a relatively short time during the Miocene, between 16 and $21 \mathrm{Myr}$ ago, in a period with a relatively deep CCD (Pälike et al. 2010).

At Site U1337, considerably different behavior of the $\delta^{44 / 40} \mathrm{Ca}_{\mathrm{pw}}$ compared to the other sediment cores can be seen. Here, the pore water $\delta^{44 / 40} \mathrm{Ca}$ value is only slightly 


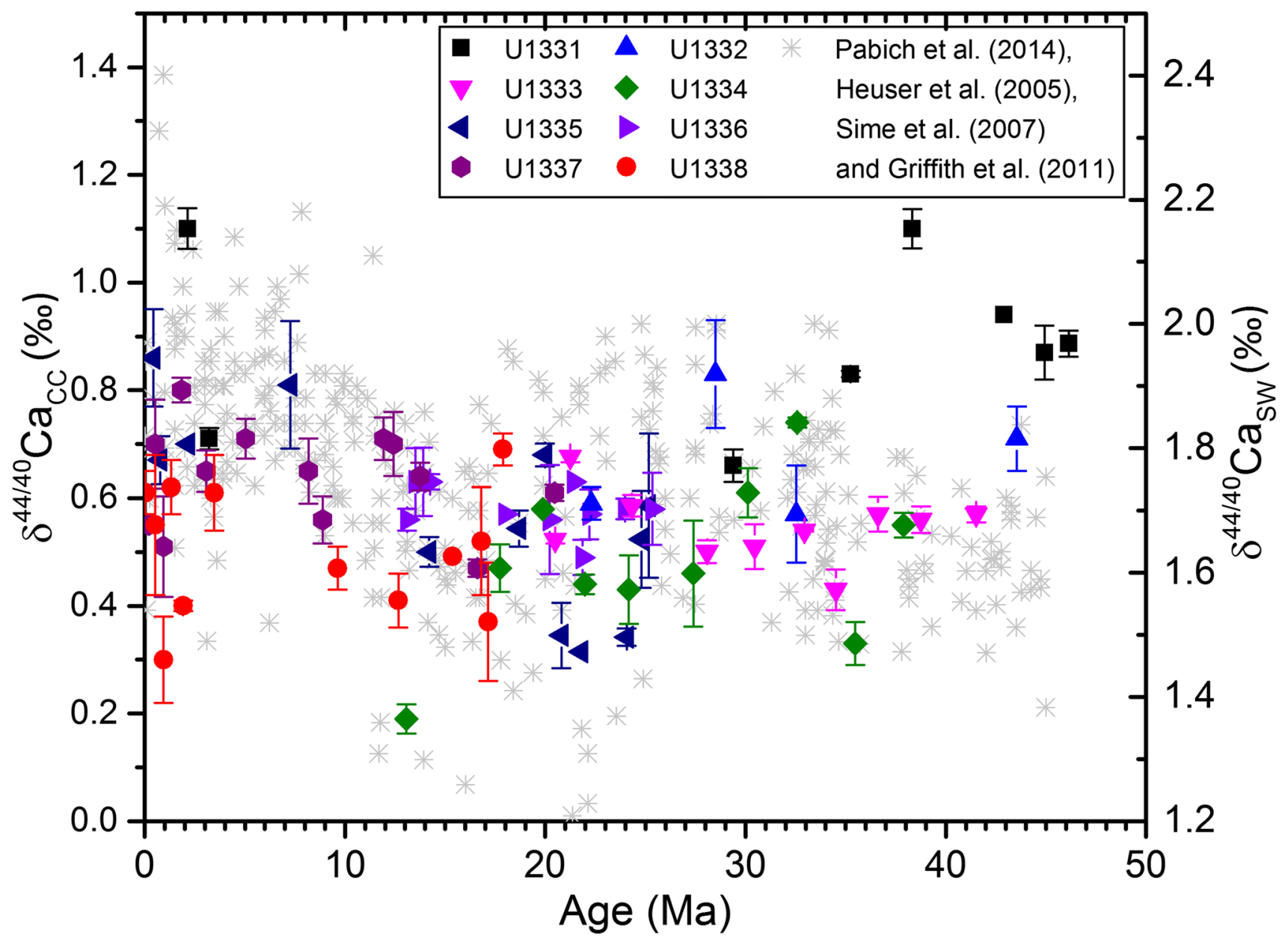

Fig. 5 The $\delta^{44 / 40} \mathrm{Ca}$ of the biogenic carbonate of the sediment $\left(\delta^{44 / 40} \mathrm{Ca}_{\mathrm{CC}}\right.$; this work) follows mainly the seawater curve over time $\left(\delta^{44 / 40} \mathrm{Ca}\right.$ sw; Griffith et al. 2011; Heuser et al. 2005; Pabich et al. 2014; Sime et al. 2007)

decreasing in the first approximately $250 \mathrm{~m}$ sediment depth (CSF). Then a sudden decrease to values even below those of the sediment is featured at the depth of a chert layer. The strong geochemical gradient at the chert layer can also be seen in the elemental concentration of $\mathrm{Li}^{+}, \mathrm{Sr}^{2+}$ (Fig. 4), and $\mathrm{Mn}^{2+}$, but not for $\mathrm{Ca}^{2+}$ (Fig. 4) and $\mathrm{Mg}^{2+}$ (Pälike et al. 2010), and is not strongly pronounced in the ${ }^{87} \mathrm{Sr} /{ }^{86} \mathrm{Sr}$ (Voigt et al. 2015; Figs. 2 and 3); therefore, the chert layer acts as a diffusion barrier (Pälike et al. 2010). While the $\mathrm{Ca}^{2+}$ concentration is not affected by this diffusion barrier, the $\delta^{44 / 40} \mathrm{Ca}_{\mathrm{pw}}$ isotope values are (Fig. 4). This suggests that $\mathrm{Ca}$ concentrations are governed by carbonate recrystallization, while $\delta^{44 / 40} \mathrm{Ca}$ is additionally influenced by $\mathrm{Ca}$ transportrelated fractionation processes. The $\delta^{44 / 40} \mathrm{Ca}_{\mathrm{pw}}$ value of $0.26 \%$ at a depth of $254.6 \mathrm{~m}$ (CSF) right underneath this chert layer indicates an ongoing carbonate recrystallization process within the sediment, leading to an enrichment of light ${ }^{40} \mathrm{Ca}$ in the pore water. This is probably in addition to a lateral flow and isotope fractionation during transport through clay-bearing sediments and interaction with charged particle surfaces. The lack of an ${ }^{87} \mathrm{Sr} /{ }^{86} \mathrm{Sr}$ signal supports the concept of a lateral transport within a layer during carbonate recrystallization and transport-related $\mathrm{Ca}$ isotope fractionation. The carbonate recrystallization rate of Site U1337 has been assumed to be different above and below the chert layer (Voigt et al. 2015). Voigt et al. (2015) interpret after Richter and Liang (1993) that the seawater-like values above the chert layer are a result of a diffusive exchange with the ocean since the $\mathrm{Ca}^{2+}$ and $\mathrm{Sr}^{2+}$ concentration gradients in this segment tend toward lower concentration in the upper part. However, a lateral diffusive flow is more capable to explain these observations, probably in conjunction with an additional upward-directed fluid flow, since the ${ }^{87} \mathrm{Sr} /{ }^{86} \mathrm{Sr}$ ratio and $\delta^{44 / 40} \mathrm{Ca}_{\mathrm{pw}}$ values indicate input from relative modern seawater above the chert layer.

The water carried by such a lateral flow is presumably discharged at a seamount flank above the chert layer possibly between stagnant zones (Fisher 2004). It is moving upwards and laterally through the sediment, while underneath the chert layer acts as a diffusion barrier (Fisher 


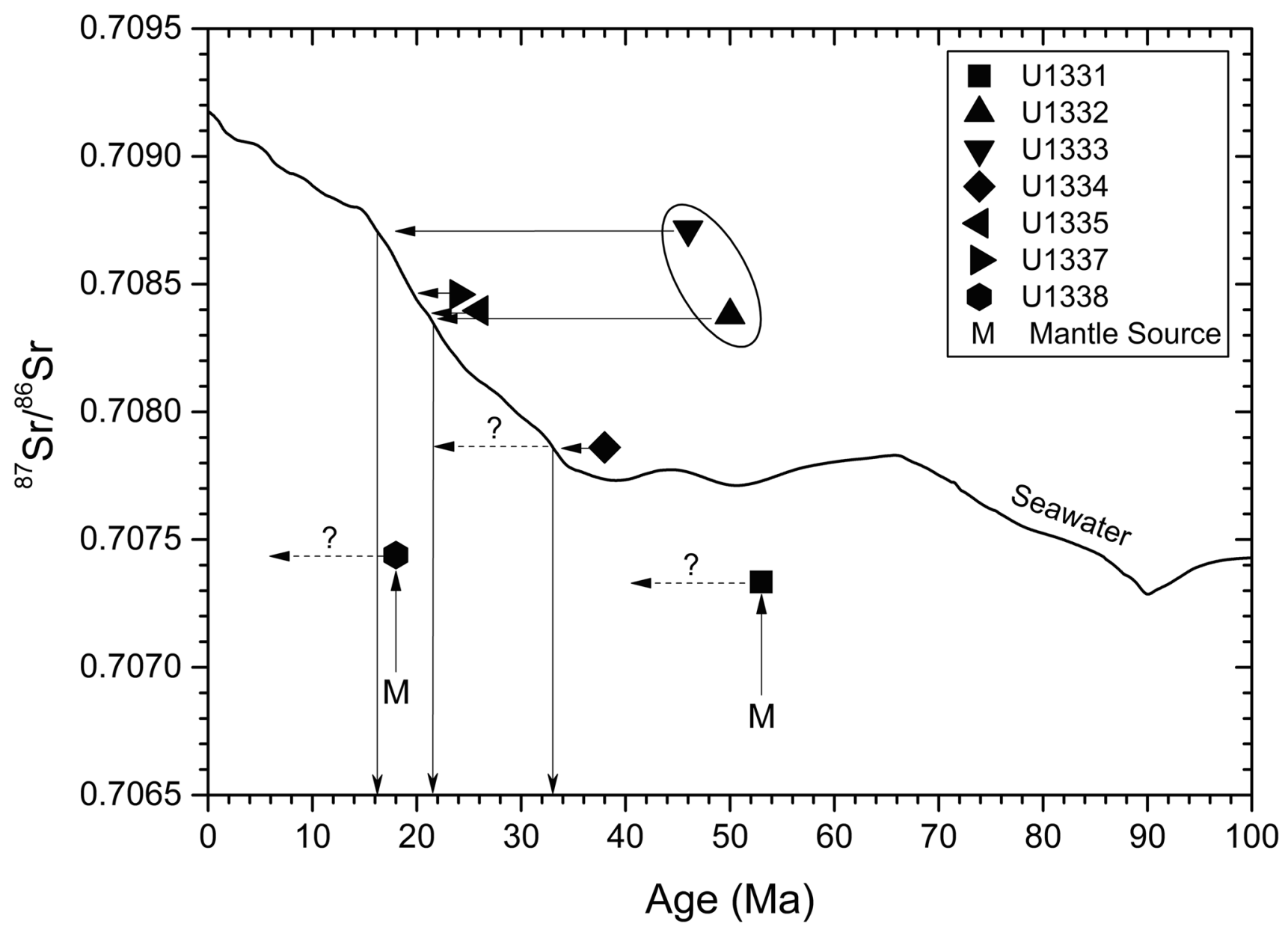

Fig. $6{ }^{87} \mathrm{Sr} /{ }^{86} \mathrm{Sr}$ isotope ratio of the oceanic crust carbonate cements as a function of crustal formation age. ${ }^{87} \mathrm{Sr} /{ }^{86} \mathrm{Sr}$ seawater curve from McArthur et al. (2001). The question marks declare while the specific

time of carbonate precipitation after oceanic crust formation is not known, a non-seawater-like fluid can be identified

2004; Pälike et al. 2010; Voigt et al. 2015). Compared to Sites U1333-U1335 which have a similar $\mathrm{CaCO}_{3}$ content, $\delta^{44 / 40} \mathrm{Ca}_{\mathrm{pw}}$ is relatively high in the upper part of Site U1337. This would imply extreme low carbonate recrystallization rates if the fluid flow is not considered. This observation rather suggests that the $\delta^{44 / 40} \mathrm{Ca}_{\mathrm{pw}}$ is elevated by modern seawater input and this hypothesis is supported by the high ${ }^{87} \mathrm{Sr} /{ }^{86} \mathrm{Sr}$ ratio. Thus, even assuming an untypically low carbonate recrystallization rate for carbonate-rich sediments, this would lead to lower modeled $\delta^{44 / 40} \mathrm{Ca}_{\mathrm{pw}}$ above the chert layer than analyzed. Underneath the chert layer toward greater depths, $\delta^{44 / 40} \mathrm{Ca}_{\mathrm{pw}}$ increase by $0.75 \%$ o within approximately $150 \mathrm{~m}$ of sediment toward seawater-like values at the basement (Fig. 2) similar to the other profiles of the other sites, but relatively low compared to the exchange of pore fluid that occurs in the upper part of the sediment column. No influence of the upper part caused by upwards-directed diffusive flow from the basement could be determined. The $\delta^{44 / 40} \mathrm{Ca}_{\mathrm{pw}}$ value and $\mathrm{CaCO}_{3}$ content of the lower parts of Sites U1337 and U1338 implies a similar carbonate recrystallization rate for the lower parts of these sites, but with a different fluid flow because of the larger increase toward seawater-like values at the sediment/basalt interface of Site U1338. The $\delta^{44 / 40} \mathrm{Ca}_{\mathrm{pw}}$ of the upper part of Site U1337 appears to be comparable with Site U1333, indicating a similar carbonate recrystallization rate of these sites. Combining the $\delta^{44 / 40} \mathrm{Ca}$ values and ${ }^{87} \mathrm{Sr} /{ }^{86} \mathrm{Sr}$ isotope ratios of the pore water with the elemental concentrations of $\mathrm{Li}^{+}$and $\mathrm{Sr}^{2+}$ (Pälike et al. 2010) of Sites U1331-U1335 and U1338, these show a seawater input from the basement apparently depending on the length of the sedimentary column and age of the basement.

Two conceptual models may explain the differences between Sites U1331 and U1338. The first hypothesis is about a temporal development of a fluid flux and carbonate recrystallization with high fluid flow rates through the sedimentary column in deep-sea environments and lets a seawater-like fluid travel through the whole sedimentary column. After a given 
time, the fluid would get released at the top of the sediment into the ocean. Thus, the uptaken seawater may not only interact with the lower part of the sediment as assumed (Fisher and Wheat 2010; Voigt et al. 2015; Villinger et al. 2017). It would also explain the flattening of the bulges of $\delta^{44 / 40} \mathrm{Ca}_{\mathrm{pw}}$ and elemental concentrations of $\mathrm{Li}^{2+}$ and $\mathrm{Sr}^{2+}$ as the offset in the ${ }^{87} \mathrm{Sr} /{ }^{86} \mathrm{Sr}$ ratio between pore water and sediment depending on age and column length in the sites from IODP Exp. $320 / 321$. Further, it would explain the offset in $\delta^{34} S$ values of the Sites 1225 and 1226 from ODP Leg 201 (Böttcher et al. 2006). The second hypothesis suggests that sediment properties like age, lithology, sediment thickness, and porosity are the main factors for the differences in $\delta^{44 / 40} \mathrm{Ca},{ }^{87} \mathrm{Sr} /{ }^{86} \mathrm{Sr}$, and element pore water profiles. The fluid flow rates depend on sediment parameters as assumed by Spinelli et al. (2004), and each site has a different behavior, depending on a change in the ocean's carbonate chemistry and the bioproduction zone at the time of sediment deposition, leading to a different sedimentary composition of the studied sites.

Because the sediment composition changes in the investigated sites owing to changes in the bioproduction in the paleo-equatorial Pacific and ocean carbonate chemistry through time, e.g., at the Eocene-Oligocene transition, it is not directly evident which of the two scenarios, the temporal development or the sediment properties, is more likely to be the main factor. To test the hypotheses, we used the $\delta^{44 / 40} \mathrm{Ca}$ of the pore water and $\mathrm{CaCO}_{3}$ leachates to model carbonate recrystallization and fluid flow rates of the individual cores.

\section{Recrystallization model}

To test which of the two hypotheses better describes the fluid flow from the basalt-sediment interface through the sedimentary column, carbonate recrystallization and fluid flow rates were determined using the model of Richter and DePaolo (1987) and Fantle and DePaolo (2007):

${ }^{40} \mathrm{Ca}_{\text {fluid }}: \frac{\partial C_{f}^{00}}{\partial t}=D_{C a}^{40} \frac{\partial_{f}^{2} C_{f}^{40}}{\partial z^{2}}-v \frac{\partial C_{\text {if }}}{\partial z}+R_{\text {precip }} M\left(k_{\text {rate }} C_{s}^{40}-K_{C a}^{40} C_{f}^{40}\right)$
${ }^{44} \mathrm{Ca}_{\text {fluid }}: \frac{\partial C_{f}^{4}}{\partial t}=\alpha_{\text {diff }}^{40-44} D_{C a}^{40} \frac{0^{2} C_{f}^{4}}{\partial z^{2}}-v \frac{\partial C_{\text {iff }}}{\partial z}+R_{\text {precip }} M\left(k_{\text {rate }} C_{s}^{44}-\alpha_{s-f} K_{C a}^{40} C_{f}^{44}\right)$

and

$$
\begin{aligned}
& { }^{40} \mathrm{Ca}_{\text {solid }}: \frac{\partial C_{s}^{40}}{\partial t}=-R_{\text {precip }}\left(k_{\text {rate }} C_{s}^{40}-K_{C a}^{40} C_{f}^{40}\right) \\
& { }^{44} \mathrm{Ca}_{\text {solid }}: \frac{\partial C_{s}^{44}}{\partial t}=-R_{\text {precip }}\left(k_{\text {rate }} C_{s}^{44}-K_{C a}^{40} C_{f}^{44}\right)
\end{aligned}
$$

According to Fantle and DePaolo (2007), calculations for the respective isotopes of the fluid $\left(\mathrm{Ca}_{\text {fluid }}\right)$ and solid $\left(\mathrm{Ca}_{\text {solid }}\right)$ need to be done separately, where $C_{f}$ (measured) and $C_{S}(=9.992 \mathrm{~mol} \mathrm{Ca} / \mathrm{kg}$ calcite; stoichiometric calcite) are the molal concentrations in the fluid and the solid, respectively. $R$ is the initial carbonate recrystallization rate of the solid phase $\left(\mathrm{Myr}^{-1}\right)$, which was determined for each site and decreases with time after sedimentation. This value was then used for the fluid flow models. $D_{C a}^{40}=D_{C a}^{\text {sedt }}=2.4 \times 10^{-6} \mathrm{~cm}^{2} / \mathrm{s}$ is the diffusion coefficient for ${ }^{40} \mathrm{Ca}$ in a sedimentary system and $M=\left(\rho_{s}(1-\varnothing) / \rho_{f} \varnothing\right)$ is the sediment parameter of the mass ratio of the solid and fluid calculated and smoothed by running average calculation for each depth with $\varnothing$ as the fluidal volume fraction. Further, $\rho_{s}$ and $\rho_{f}$ are the density of the carbonates and pore water, respectively. The variable $z$ is the depth in the sedimentary column, and the diffusive fractionation factor in aqueous solutions is given as $\alpha_{\text {diff }}^{40-44}=0.99956$ (Bourg et al. 2010). $K$ stands for the equilibrium distribution coefficient and the rate of the distribution coefficient $k_{\text {rate }}=\frac{R_{\text {diss }}}{R_{\text {precip }}}$ is constant. While Richter and DePaolo (1987) choose 0 as value for the fluid velocity rate $(v)$, most of the sites of this study require $v \neq 0$, shown by a model calculation with $v=0$ (Fig. 7a, see Sect. 4.2 and Supplementary information 2).

The model of the present study is written in Fortran and Python. The second Runge-Kutta update method has been used to increase the accuracy of the calculations (Gottlieb et al. 2001), instead of the Euler approach used in previous models.

\section{Basement fluid flux}

To explain the increase of $\delta^{44 / 40} \mathrm{Ca}_{\mathrm{pw}}$ from the crust-sediment interface, we implement a fluid flow into the model as described by Richter and DePaolo (1987). We take into account the crustal evolution (e.g., plate creation, plate cooling, creation of seamounts and/or bathymetric pits, and the start of seawater uptake) and sedimentation, and define a starting point of the fluid flow at $500 \mathrm{kyr}$ after crust formation. We test four different fluid-flux models, with increasing complexity: (1) a fluid velocity equal to zero, (2) a constant fluid flow rate, (3) a linear increasing fluid flow rate over time, and (4) a time-dependent fluid flow rate involving the crustal evolution, which is closest to the natural fluid flow evolution. Parameters are described in the Supplementary information 2 and Fig. 7. Further information and applied values are provided in Table 2.

We expressed the fluid velocity equation as a standard continuity equation. Such a general type of conservation law can be written as

$\frac{\partial C_{f}}{\partial t}+\nabla *\left(v C_{f}\right)=\frac{\partial C_{f}}{\partial t}+\sum_{i=1}^{N_{\text {dim }}} \frac{\partial\left(v_{i} C_{f, i}\right)}{\partial x_{i}}=0$,

where $C_{f}$ is a conservation quantity and $v(x, t)$ is a fluid flux coefficient with a possible dependency on both space and time. The Nabla operator $(\nabla *)$ is applied to the fluid 

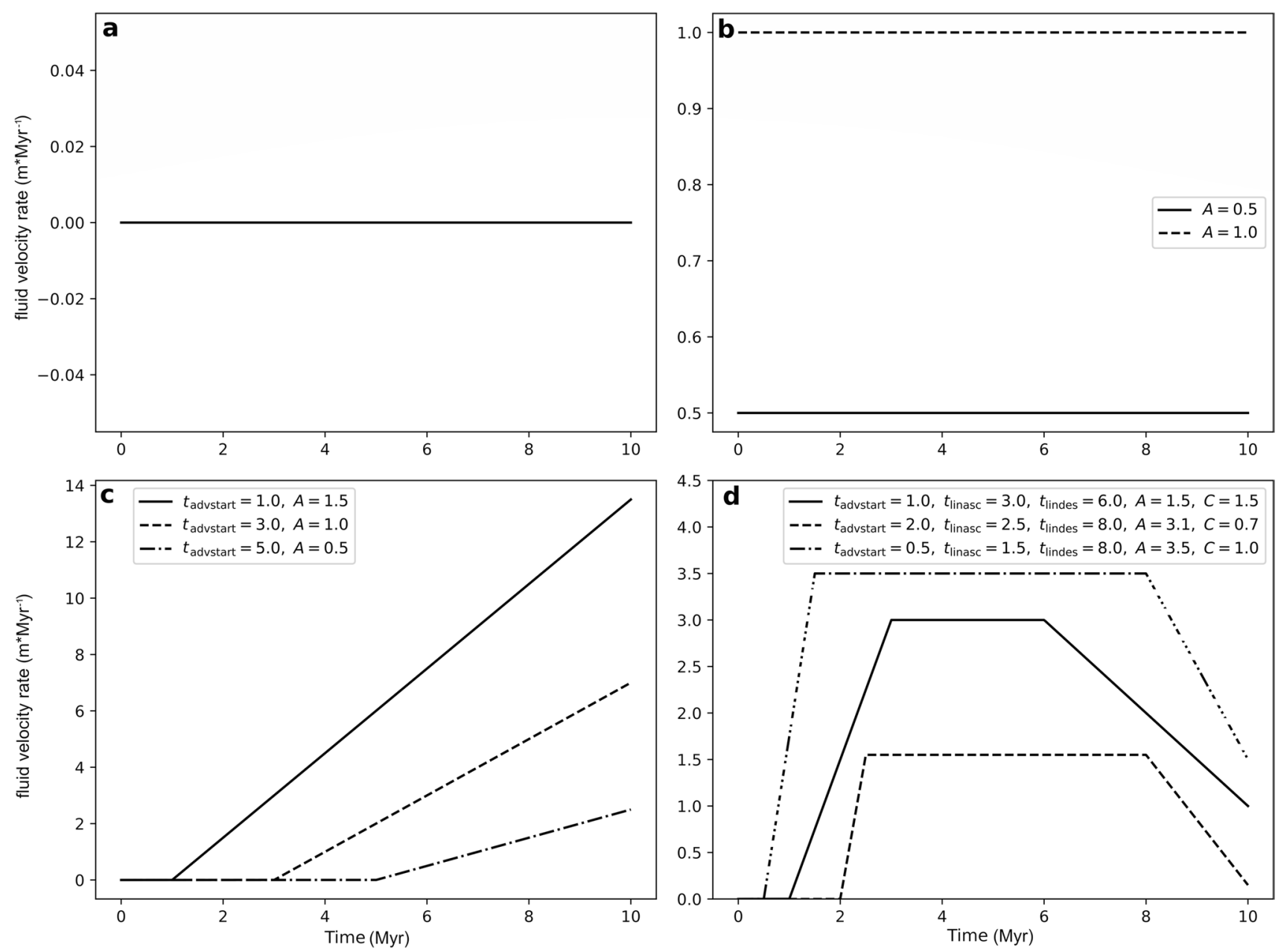

Fig. 7 Illustration of the four different model setups (for more information, see Supplementary information 2). a: fluid velocity rate $=0$; b: fluid velocity rate is constant over time; c: linear increasing fluid velocity rate with adjustable starting point; d: time dependency of fluid velocity rate. If the crustal plate evolution is considered, $d$ is the

velocity part of Eq. (4) to obtain its divergence, i.e., to produce a scalar field representing the local fluid flux of the respective conserved quantity. Since we are dealing with only one spatial dimension (namely the $z$-direction), Eq. (4) simplifies into a one-dimensional conservation Eq. (5):

$\frac{\partial C_{f}}{\partial t}+\frac{\partial\left(v(z, t) C_{f}\right)}{\partial z}=0$.

These conservation laws need to be fulfilled for each chemical species.

In cases where the spatial and temporal dependencies of the fluid velocity coefficient $v$ can be neglected, Eq. (5) further simplifies to fluid velocity Eq. (6):

$\frac{\partial C_{i, f}}{\partial t}=-v \frac{\partial C_{f}}{\partial z}$. most likely scenario. A is the linear increasing phase, B is the constant phase and refers to $\mathrm{B}=$ time linear decreasing (tlindes) - time linear ascending (tlinasc) of Eq. (10) (see Supplementary information 2 ), and $\mathrm{C}$ is the decreasing phase. Shown values are for demonstration purposes

The time-dependent initial carbonate recrystallization rates of the presented sites have been determined by best fit to be between $0.000013 \mathrm{e}^{-\mathrm{t} / 15.5}$ and $0.0038 \mathrm{e}^{-\mathrm{t} / 100.5}$ for the different sites (Table 2). It is noteworthy that the carbonate recrystallization rate is always lower than those of sediments of deep-sea plateaus or continental slopes by a factor of 100-1000 (e.g., Fantle and DePaolo 2007; Higgins and Schrag 2012). The model using the time depending change of the fluid velocity rate (Fig. 7d, Eq. 10 in the Supplementary information 2) provides the best fit for the measured data.

Since Site U1336 is not sampled down to the basement and Site U1337 is divided by a chert layer into two separate parts, a model run has not been performed for these sites. While the 1D model works for most sites, it has some limitations in the case of Site U1337, where a decoupled lateral 
Table 2 Determined carbonate recrystallization and fluid velocity rates used for the model

\begin{tabular}{|c|c|c|c|c|c|c|c|c|}
\hline Site & Model type & $\mathrm{R}$ & t_fv start (Ma) & t_linasc $(\mathrm{Ma})$ & t_lindes (Ma) & $\begin{array}{l}\mathrm{A} \\
\left(\mathrm{m} * \mathrm{Ma}^{-1}\right)\end{array}$ & $\begin{array}{l}\mathrm{C} \\
\left(\mathrm{m} * \mathrm{Ma}^{-1}\right)\end{array}$ & $\begin{array}{l}\max \mathrm{fv} \\
\left(\mathrm{m} * \mathrm{Ma}^{-1}\right)\end{array}$ \\
\hline U1331 & $\begin{array}{l}\qquad \mathrm{v}=0 \\
\text { const. } \mathrm{v} \\
\text { lin. } \mathrm{v} \\
\text { t.d.c } \mathrm{v}\end{array}$ & $0.000013 e^{\left(\frac{-t}{15.5}\right)}$ & $\begin{array}{l}- \\
0.5 \\
0.5 \\
0.5\end{array}$ & $\begin{array}{l}- \\
- \\
- \\
2\end{array}$ & $\begin{array}{l}- \\
- \\
- \\
4.8\end{array}$ & $\begin{array}{l}- \\
1.8 \\
0.06 \\
1\end{array}$ & $\begin{array}{l}- \\
- \\
- \\
0.01\end{array}$ & $\begin{array}{l}0 \\
1.8 \\
3.18 \\
2\end{array}$ \\
\hline U1332 & $\begin{array}{l}\qquad \mathrm{v}=0 \\
\text { const. } \mathrm{v} \\
\text { lin. } \mathrm{v} \\
\text { t.d.c } \mathrm{v}\end{array}$ & $0.000018 e^{\left(\frac{-t}{30.5}\right)}$ & $\begin{array}{l}- \\
0.5 \\
0.5 \\
0.5\end{array}$ & $\begin{array}{l}- \\
- \\
- \\
1.5\end{array}$ & $\begin{array}{l}- \\
- \\
- \\
4.3\end{array}$ & $\begin{array}{l}- \\
0.9 \\
0.016 \\
0.6\end{array}$ & $\begin{array}{l}- \\
- \\
- \\
0.01\end{array}$ & $\begin{array}{l}0 \\
0.9 \\
0.896 \\
0.9\end{array}$ \\
\hline U1333 & $\begin{array}{l}\qquad \mathrm{v}=0 \\
\text { const. } \mathrm{v} \\
\text { lin. } \mathrm{v} \\
\text { t.d.c } \mathrm{v}\end{array}$ & $0.000075 e^{\left(\frac{-t}{8.04}\right)}$ & $\begin{array}{l}- \\
0.5 \\
0.5 \\
0.5\end{array}$ & $\begin{array}{l}- \\
- \\
- \\
1.5\end{array}$ & $\begin{array}{l}- \\
- \\
- \\
4.3\end{array}$ & $\begin{array}{l}- \\
0.42 \\
0.009 \\
0.28\end{array}$ & $\begin{array}{l}- \\
- \\
- \\
0.009\end{array}$ & $\begin{array}{l}0 \\
0.42 \\
0.414 \\
0.42\end{array}$ \\
\hline U1334 & $\begin{array}{l}\qquad \mathrm{v}=0 \\
\text { const. } \mathrm{v} \\
\text { lin. } \mathrm{v} \\
\text { t.d.c } \mathrm{v}\end{array}$ & $0.00006 e^{\left(\frac{-t}{250}\right)}$ & $\begin{array}{l}- \\
0.5 \\
0.5 \\
0.5\end{array}$ & $\begin{array}{l}- \\
- \\
- \\
2\end{array}$ & $\begin{array}{l}- \\
- \\
- \\
5.8\end{array}$ & $\begin{array}{l}- \\
3 \\
0.12 \\
1.8\end{array}$ & $\begin{array}{l}- \\
- \\
- \\
0.05\end{array}$ & $\begin{array}{l}0 \\
3 \\
4.56 \\
3.6\end{array}$ \\
\hline U1335 & $\begin{array}{l}\qquad \mathrm{v}=0 \\
\text { const. } \mathrm{v} \\
\text { lin. } \mathrm{v} \\
\text { t.d.c } \mathrm{v}\end{array}$ & $0.000033 e^{\left(\frac{-t}{100}\right)}$ & $\begin{array}{l}- \\
0.5 \\
0.5 \\
0.5\end{array}$ & $\begin{array}{l}- \\
- \\
- \\
2\end{array}$ & $\begin{array}{l}- \\
- \\
- \\
5\end{array}$ & $\begin{array}{l}- \\
10 \\
0.45 \\
6.5\end{array}$ & $\begin{array}{l}- \\
- \\
- \\
0.2\end{array}$ & $\begin{array}{l}0 \\
10 \\
11.7 \\
13\end{array}$ \\
\hline U1338 & $\begin{array}{l}\qquad \mathrm{v}=0 \\
\text { const. } \mathrm{v} \\
\text { lin. } \mathrm{v} \\
\text { t.d.c } \mathrm{v}\end{array}$ & $0.00038 e^{\left(\frac{-t}{100.5}\right)}$ & $\begin{array}{l}- \\
0.5 \\
0.5 \\
0.5\end{array}$ & $\begin{array}{l}- \\
- \\
- \\
1.9\end{array}$ & $\begin{array}{l}- \\
- \\
- \\
6.9\end{array}$ & $\begin{array}{l}- \\
11 \\
0.5 \\
10\end{array}$ & $\begin{array}{l}- \\
- \\
- \\
1\end{array}$ & $\begin{array}{l}0 \\
11 \\
9 \\
19\end{array}$ \\
\hline $807 \mathrm{~A}^{\#}$ & $\mathrm{v}=0$ & $0.091 e^{\left(\frac{-t}{140}\right)}$ & - & - & - & - & - & - \\
\hline $590 \mathrm{~B}^{\# \#}$ & $\mathrm{v}=0$ & $0.151 e^{\left(\frac{-t}{50}\right)}$ & - & - & - & - & - & - \\
\hline $\mathrm{U} 1336^{\mathrm{a}}$ & $\mathrm{v}=0$ & $0.05225 e^{\left(\frac{-t}{30}\right)}$ & - & - & - & - & - & - \\
\hline $\mathrm{U} 1338^{\mathrm{a}}$ & $\mathrm{v}=0$ & $0.0625 e^{\left(\frac{-t}{80}\right)}$ & - & - & - & - & - & - \\
\hline
\end{tabular}

"v $=0$ " refers to no fluid velocity (Fig. 7a), "const. v." to constant fluid velocity rate (Fig. 7b), "lin. v." to linear increasing fluid velocity rate (Fig. 7c), and "t.d.c. v." to time depending change of fluid velocity rate (Fig. 7d); "t_lin asc" and "t_lin_des" is the timespan where the fluid velocity linearly increases and the timespan where the fluid velocity linearly decreases, respectively. A refers to the fluid velocity rate of the linearly increasing phase and $C$ of the linearly decreasing phase. The term " $\mathrm{t}$ fv start" is the starting point of the modeled fluid velocity after a given time after crust formation, taking the crustal building and beginning of sedimentation into account. The maximal fluid velocity rate is given as "max fv". For more details about the different model types, please see Supplementary material 2. 807A" from Higgins and Schrag (2012), 590B" from Richter and DePaolo (1987), U1336 a and U1338 ${ }^{\mathrm{a}}$ from Voigt et al. (2015)

fluid flow from the upward-directed fluid flow seems to take place. This is the reason why the model has not been performed on these sites.

\section{Comparison of analyzed data and model results}

The model was developed to test the two hypotheses, if Sites U1331-U1338 show a time-series evolution of typical deep-sea sediment or if each site has a different behavior owing to their sediment composition, depositional history, and location.

Since marine pore water primarily consists of ocean water trapped in the sediment pore space, the $\delta^{44 / 40} \mathrm{Ca}_{\mathrm{pw}}$ should follow the $\delta^{44 / 40} \mathrm{Ca}$ seawater curve (Griffith et al. 2011; Heuser et al. 2005; Sime et al. 2007) if no carbonate recrystallization occurs, whereas sediment carbonate is about $1-1.2 \%$ o lighter owing to fractionation between seawater and biominerals (Fig. 5). With carbonate recrystallization and without fluid flow, the $\delta^{44 / 40} \mathrm{Ca}_{\mathrm{pw}}$ of the deep-sea sediments would show patterns similar to those of the sediments of deep-sea plateaus (Fantle and DePaolo 2007). Since ${ }^{87} \mathrm{Sr} /{ }^{86} \mathrm{Sr}$ does not fractionate during incorporation within biogenic carbonate, the ${ }^{87} \mathrm{Sr} /{ }^{86} \mathrm{Sr}$ of the pore water should be equalized with the sediment. Therefore, in carbonate-rich sediments, it should follow the Sr isotope seawater curve (e.g., McArthur et al. 2001), which is, however, not the case in these sites (Fig. 3). The sites with the lowest (U1331) and highest (U1338) modeled carbonate recrystallization rates and 
with the highest (U1338) and third-lowest (U1331) modeled fluid velocity rate (Fig. 9, Table 2) reveal less radiogenic ${ }^{87} \mathrm{Sr} /{ }^{86} \mathrm{Sr}$ in the carbonate cement of the basalts pore space than even 100-Myr-old seawater (Fig. 6), which is far older compared to the crustal age and consequently the sedimentary cover. Therefore, these sites appear to have an input of a mantle-derived source, such as MORB or hydrothermal fluids. Considering the measured ${ }^{87} \mathrm{Sr} /{ }^{86} \mathrm{Sr}$ and the $\delta^{44 / 40} \mathrm{Ca}$ data in addition to the model, these mantle source inputs tend to be dominantly a vertical flow in the case of Site U1338 and a lateral flow in case of Site U1331. This effect could be driven owing to the site location, for example, in a depression or on a ridge, and probably due to the proximity to, e.g., a seamount.

The element concentrations of $\mathrm{Li}^{+}$and $\mathrm{Sr}^{2+}$ (Fig. 4) and the isotope measurements of ${ }^{87} \mathrm{Sr} /{ }^{86} \mathrm{Sr}$ and $\delta^{44 / 40} \mathrm{Ca}$ pw (Figs. 2 and 3) reveal a composition similar to modern seawater throughout the whole sediment columns of Sites U1331-U1333 and in the upper part of Site U1337, indicating a higher fluid flux than modeled (Figs. 8 and 9) and higher than the possible fluid flux predicted by the low heat flux (see Fisher 2004 and Pälike et al. 2010). However, if in Site U1331 a high upward-directed fluid flux would occur, the isotopic signature of the turbidite would have been overprinted since it would be pushed upwards as well. Further,
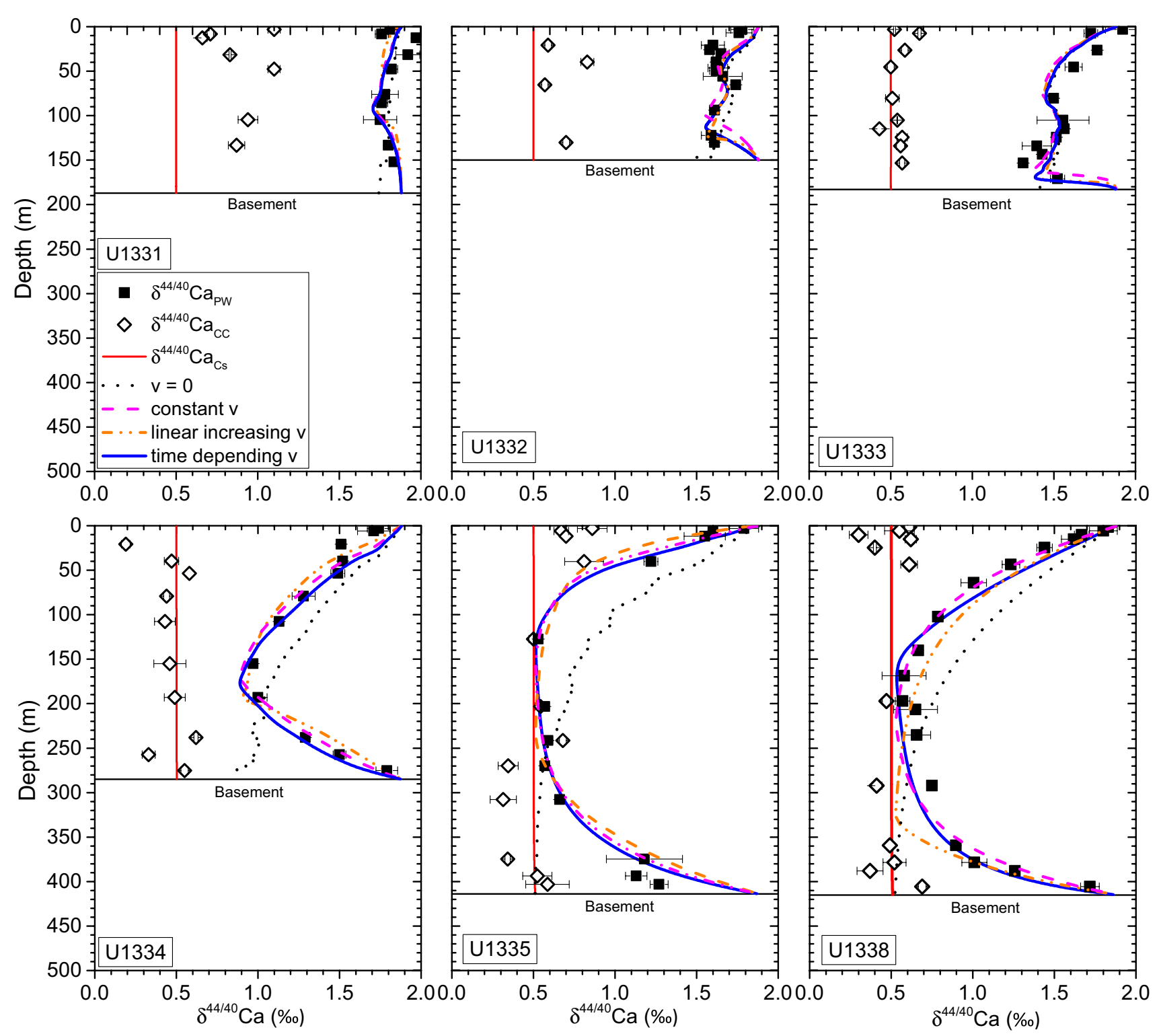

Fig. 8 Best-fit model calculations compared to the measured Ca isotope data. Different colors refer to the different model setups of the fluid velocity rate ( $v$ ) with $v=0$ (Fig. 7a; Eq. 7), $v=$ constant (Fig. 7b;
Eq. 8), $v=$ linearly increasing (Fig. 7c, Eq. 9), and $v=$ time dependent (Fig. 7d; Eq. 10). Depth is given in $\mathrm{CSF}=$ core depth below seafloor. For equations, see Supplementary information 2 
Fig. 9 Initial carbonate recrystallization rates $\left(R_{\text {initial }}\right)$ and maximum fluid velocity rates $\left(v_{\max }\right)$ of Sites U1331-U1335 and U1338, determined by the model using the time-dependent fluid velocity rate (Fig. 7d)

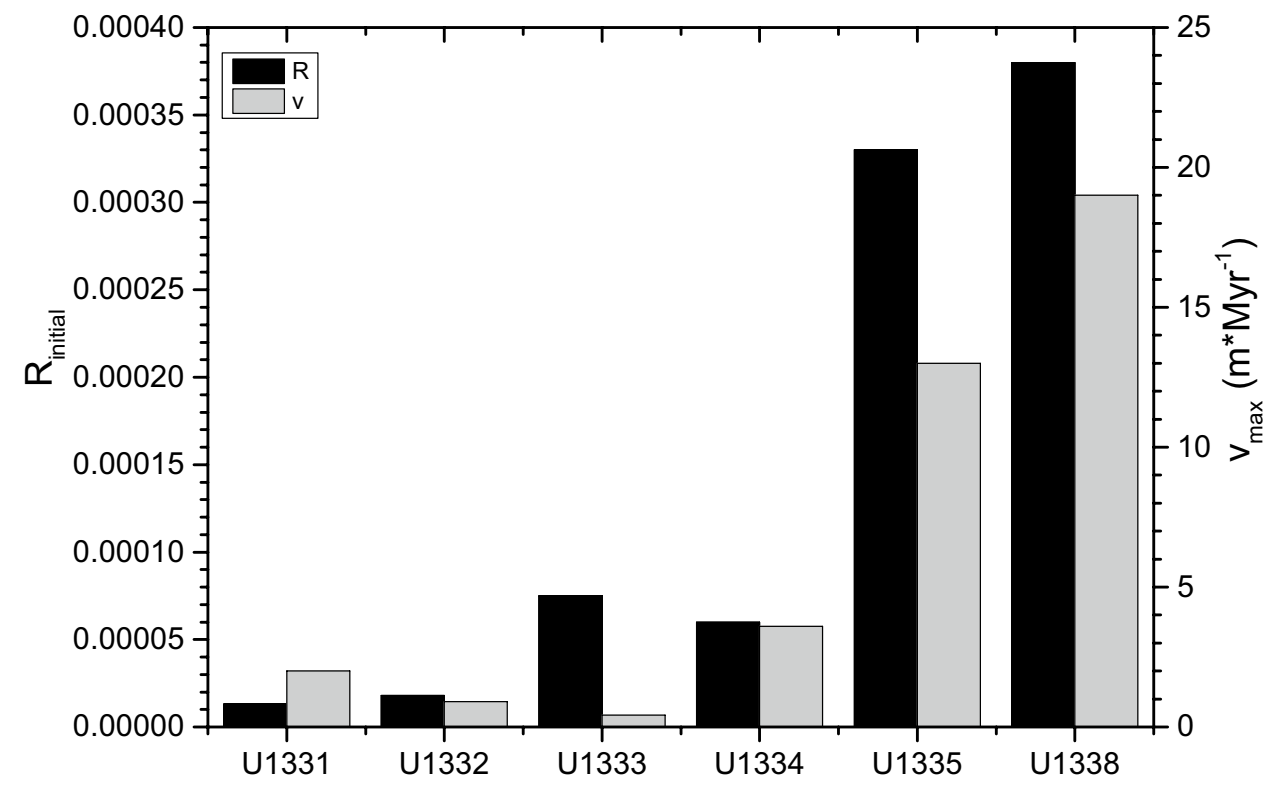

a hypothetically very high modeled carbonate recrystallization rate in addition to a high fluid flux would lead to a strongly pronounced increase in the $\delta^{44 / 40} \mathrm{Ca}$ of the solid $\mathrm{CaCO}_{3}$ toward seawater-like values, thus a high fluid flux and high carbonate recrystallization rate are unlikely in Sites U1331-U1333 and U1337.

Nevertheless, the sedimentary composition of Site U1331 and Site U1332 consists mainly of clay minerals, thus having a low carbonate content which can recrystallize. The turbidite layer of Site U1331 contains more $\mathrm{CaCO}_{3}$ than other layers of this site and probably owing to this change in the carbonate content, the model may not reproduce sites with alternating carbonate content accurately. However, in case of Site U1332 and probably even Site U1333, higher fluxes would have overprinted the recognizable double bulges owing to the considered sediment sensitive parameter $M$. On the other hand, the model including an upward-directed fluid flux from the basalt-sediment interface is only able to reproduce the measured data with a low initial carbonate recrystallization rate of between $0.000013 \mathrm{e}^{(-\mathrm{t} / 15.5)}$ and $0.000075 \mathrm{e}^{(-\mathrm{t} / 8.04)}$ for Sites U1331 and U1333. These rates are about a factor of 1000 smaller than determined for deepsea plateau sediments, which may be explained by the lower carbonate content (Fantle and DePaolo 2007; Higgins and Schrag 2012). The low carbonate recrystallization rates come together with a low maximum fluid velocity between 0.42 and 2-3 $\mathrm{m}^{*} \mathrm{Myr}^{-1}$ (Table 2; Fig. 9). It is noteworthy that Site U1333 shows the lowest modeled maximum fluid velocity of all investigated sites and a higher initial carbonate recrystallization rate than the younger Site U1334, contradicting the hypotheses of the time evolution series of the fluid flux of the Sites of IODP Exp. 320/321 transect. The model also demonstrates that even these low rates can lead to an increase of $\delta^{44 / 40} \mathrm{Ca}$ pw back to seawater-like values at the sediment-basalt interface; nevertheless, it also shows that the older sediment cores have lower initial carbonate recrystallization and fluid velocity rates in this age transect.

Site U1334 shows a small increase both in the initial carbonate recrystallization rate $\left(0.00006 \mathrm{e}^{(-\mathrm{t} / 250)}\right)$ and maximum fluid velocity (3.6 m* $\mathrm{Myr}^{-1}$ ) compared to Sites U1331 and U1332, while Sites U1335 and U1338 have the overall highest rates. Our modeled initial carbonate recrystallization rates for the latter two sites are still by a factor of $\sim 100$ smaller than sediments of deep-sea plateaus.

The younger Sites U1335 and U1338, which have the thickest sediment cover and the highest carbonate content, reveal a modeled high initial carbonate recrystallization rate of $0.00033 \mathrm{e}^{(-\mathrm{t} / 100.5)}$ and $0.00038 \mathrm{e}^{(-\mathrm{t} / 100)}$, respectively. The modeled maximum fluid velocity rate is 13 and $19 \mathrm{~m}^{*} \mathrm{Myr}^{-1}$, respectively (Figs. 8 and 9; Table 2). In the case of Site $\mathrm{U} 1338$, the recrystallization rate determined by $\mathrm{Ca}$ isotopes seems to be lower than the recrystallization rates calculated by Voigt et al. (2015) (Table 2) using Sr isotopes. Differences in $\mathrm{Sr}$ - and $\mathrm{Ca}$-derived recrystallization rates are not unusual, as earlier described by Fantle and DePaolo (2006) and Fantle and DePaolo (2007), which observed a difference of about $35 \%$ between the modeled recrystallization rates of $\mathrm{Sr}$ and Ca. However, the model of Voigt et al. (2015) does not implement a fluid flux and uses an averaged sediment property value $M$ for all depths, which may explain the differences between the models. A calculation with the fixed $M$ value used by Voigt et al. (2015) in our Ca model leads to even lower $R$ value than we determined. A variable $M$ value calculated by the sediment parameters for each depth is preferable to a fixed $M$ value since the changes in the natural system can be better modeled in this way. 
Further, not only the carbonate recrystallization rate and fluid velocity are decreasing with the increasing ages of the investigated sites, but also the sediment thickness (Table 1, Fig. 8) and the $\mathrm{CaCO}_{3}$ content (see Supplementary information 1) are decreasing as well, suggesting that the carbonate recrystallization and fluid velocity are controlled by the lithology. This indicates that in a special case of a short carbonate-rich sediment column in the neighborhood of an active zone such as a seamount, the sediment column probably could be completely flushed with modern seawater and acts as a source of light ${ }^{40} \mathrm{Ca}$ back to the ocean.

Taking the location and geomorphology of the sites into account, the fluid flow does probably not only depend on the sedimentary composition and the distance to the spreading zone, and therefore the crustal age, but possibly also on the distance to a seamount and the orographic height as well. For example, Site U1331 is located in a depression about $10 \mathrm{~km}$ away from a seamount, thus supporting the hypothesis of a possible high lateral flow that is traveling through the sediments of this depression. Site U1335 is located near two seamounts with a distance of about 15 and $20 \mathrm{~km}$ and Site U1338 is about $20 \mathrm{~km}$ away from a seamount (for detailed information about the site locations, see Pälike et al. 2010). The modeled high fluid velocity rates of the two Sites U1335 and U1338 and the proximity to the spreading zone, therefore more active recharging and discharging, and the closer localization of Site U1331 to a now less active seamount can be explained by an increasing upward-directed fluid flow owing to heat exchange over distance (Langseth and Herman 1981).

Combining the measured with the modeled data, the hypothesis that carbonate recrystallization and fluid flux depend on the sites' location and sediment composition is more plausible.

\section{Conclusion}

We implemented a time-depending change of the fluid velocity rate into a carbonate recrystallization model, which is able to reproduce the measured $\delta^{44 / 40} \mathrm{Ca}$ of the pore water of Sites U1331-U1338 of IODP Exp. 320/321. Pore-water profiles of the studied deep-sea sediments show characteristic $\delta^{44 / 40} \mathrm{Ca}$ and ${ }^{87} \mathrm{Sr} /{ }^{86} \mathrm{Sr}$ pattern: some sites with relatively short sediment columns and low carbonate content show only seawater-like pore water in disequilibrium with the sediment. With increasing sediment thickness and carbonate content, $\delta{ }^{44 / 40} \mathrm{Ca}$ and ${ }^{87} \mathrm{Sr} /{ }^{86} \mathrm{Sr}$ of the pore water converge with sediment values in the middle of the profiles due to carbonate recrystallization. In the lower part of the sedimentary column, the $\delta^{44 / 40} \mathrm{Ca}$ and ${ }^{87} \mathrm{Sr} /{ }^{86} \mathrm{Sr}$ values of the pore water increase toward the basement until they approach seawater values at the basalt-sediment interface. This increase is related to an input of a fluid with seawater-like values. The difference between these two settings can be explained by modeling the carbonate recrystallization and fluid velocity rates of the respective sites. The ${ }^{87} \mathrm{Sr} /{ }^{86} \mathrm{Sr}$ and the $\delta^{44 / 40} \mathrm{Ca}$ of the pore water samples indicate high fluid fluxes at Sites U1331-U1333 and in the upper part of Site U1337. However, the sediment composition, sedimentary column length, the low concentration gradient of $\mathrm{Sr}^{2+}$ and $\mathrm{Ca}^{2+}$, the low heat flow (Pälike et al. 2010), and the model meanwhile indicate low upward-directed fluid fluxes. Although no recrystallization and fluid flow modeling has been conducted on Site U1337, because our model is designed for 1-D fluid flow only, our results imply a highly diffusive, probably even advective lateral flow of uptaken seawater at this site above the chert layer. Since Site U1331 is located in a depression in the neighborhood of a seamount, a lateral flow in a fluid flow zone presumably leads to recent seawater values throughout the entire depth profile of the core.

Following this line of evidence, a deep-sea sedimentary column deposited near bathymetric pits or seamounts is even after millions of years able to be recharged for a certain time with recent seawater. Therefore, some deep-sea sites can be part of global geochemical cycling processes, for example, the carbon cycle, affecting the buffer capacity of the oceanic system for carbon.

Supplementary Information The online version contains supplementary material available at https://doi.org/10.1007/s00367-021-00720-9.

Acknowledgements We would like to thank Matt Fantle and Michael Willig for valuable information and fruitful discussions about the carbonate recrystallization modeling and Erik Scherer for improvement of an earlier draft of this manuscript. Further, we thank Heide-Marie Baier and Frank Deipenwisch for assistance and maintenance in the laboratory, Marcel Schälling and Milena Waag for support on sample preparation, as well as Captains and Crews of IODP Exp. 320 and 321. We thank IODP for providing pore water and sediment samples used in this study. For valuable comments that helped to improve this manuscript, we would like to thank Zvi Steiner and an anonymous reviewer as well as Gabriele Uenzelmann-Neben for the editorial handling.

Author contribution A.W. prepared the samples, carried out the isotope analysis, and took lead in writing the manuscript. A.W. and D.D. developed the model calculations. A.W., N.G., and B.M.A.T. developed the data interpretation. N.G. carried out sample collection on board the Joides Resolution. B.M.A.T. and N.G. developed the project. All authors contributed to the manuscript writing.

Funding Open Access funding enabled and organized by Projekt DEAL. This work was supported by the Deutsche Forschungsgemeinschaft by grants TE $642 / 4$ and GU $1035 / 6$ to B.M.A.T. and N.G.

Data availability All data generated or analyzed during this study are included in this published article and its supplementary information files. 


\section{Declarations}

Competing interests The authors declare no competing interests.

Open Access This article is licensed under a Creative Commons Attribution 4.0 International License, which permits use, sharing, adaptation, distribution and reproduction in any medium or format, as long as you give appropriate credit to the original author(s) and the source, provide a link to the Creative Commons licence, and indicate if changes were made. The images or other third party material in this article are included in the article's Creative Commons licence, unless indicated otherwise in a credit line to the material. If material is not included in the article's Creative Commons licence and your intended use is not permitted by statutory regulation or exceeds the permitted use, you will need to obtain permission directly from the copyright holder. To view a copy of this licence, visit http://creativecommons.org/licenses/by/4.0/.

\section{References}

Ahm A-SC, Maloof AC, Macdonald FA, Hoffman PF, Bjerrum CJ, Bold U, Rose CV, Strauss JV, Higgins JA (2019) An early diagenetic deglacial origin for basal Ediacaran "cap dolostones." Earth Planet Sci Lett 506:292-307

Ahm A-SC, Bjerrum CJ, Blättler CL, Swart PK, Higgins JA (2018) Quantifying early marine diagenesis in shallow-water carbonate sediments. Geochim Cosmochim Acta 236:140-159

Bekins BA, Spivack AJ, Davis EE, Mayer LA (2007) Dissolution of biogenic ooze over basement edifices in the equatorial Pacific with implications for hydrothermal ventilation of the oceanic crust. Geol 35(8):679

Berger WH (1989) Global maps of ocean productivity. In: Berger, W.H., Smetacek, V.S., Wefer, G. (Eds.), Productivity of the oceans. Present and pastardback. John Wiley and Sons, New York, pp. 429-455

Böttcher ME, Ferdelman TG, Jørgensen BB, Blake RE, Surkov AV, Claypool GE (2006) Sulfur isotope fractionation by the deep biosphere within sediments of the Eastern Equatorial Pacific and Peru Margin. In: Jørgensen, B.B., D'Hondt, S.L., Miller, D.J. (Eds.), Proceedings of the Ocean Drilling Program, 201 Scientific Results, vol. 201. Ocean Drilling Program

Bourg IC, Richter FM, Christensen JN, Sposito G (2010) Isotopic mass dependence of metal cation diffusion coefficients in liquid water. Geochim Cosmochim Acta 74(8):2249-2256

Bowles MW, Mogollón JM, Kasten S, Zabel M, Hinrichs K-U (2014) Global rates of marine sulfate reduction and implications for sub-sea-floor metabolic activities. Science (New York, N.Y.) 344(6186):889-891

Bradbury H, Turchyn A (2018) Calcium isotope fractionation in sedimentary pore fluids from ODP Leg 175: resolving carbonate recrystallization. Geochim Cosmochim Acta 236:121-139

D’Hondt S, Jørgensen BB, Miller DJ, Batzke A, Blake R, Cragg BA, Cypionka H, Dickens GR, Ferdelman T, Hinrichs K-U, Holm NG, Mitterer R, Spivack A, Wang G, Bekins B, Engelen B, Ford K, Gettemy G, Rutherford SD, Sass H, Skilbeck CG, Aiello IW, Guèrin G, House CH, Inagaki F, Meister P, Naehr T, Niitsuma S, Parkes RJ, Schippers A, Smith DC, Teske A, Wiegel J, Padilla CN, Acosta JLS (2004) Distributions of microbial activities in deep subseafloor sediments. Science (New York, N.Y.) 306(5705):2216-2221

Fantle MS, DePaolo DJ (2006) Sr isotopes and pore fluid chemistry in carbonate sediment of the Ontong Java Plateau: calcite recrystallization rates and evidence for a rapid rise in seawater
$\mathrm{Mg}$ over the last 10 million years. Geochim Cosmochim Acta 70(15):3883-3904

Fantle MS, DePaolo DJ (2007) Ca isotopes in carbonate sediment and pore fluid from ODP Site 807A: the $\mathrm{Ca} 2+(\mathrm{aq})-$ calcite equilibrium fractionation factor and calcite recrystallization rates in Pleistocene sediments. Geochim Cosmochim Acta 71(10):2524-2546

Fantle MS, Tipper ET (2014) Calcium isotopes in the global biogeochemical Ca cycle: implications for development of a Ca isotope proxy. Earth Sci Rev 129:148-177

Fisher AT (2004) Rates of flow and patterns of fluid circulation. In: Davis EE, Elderfield H (eds) Hydrogeology of the oceanic lithosphere. Cambridge Univ. Press, Cambridge

Fisher AT (2005) Marine hydrogeology: recent accomplishments and future opportunities. Hydrogeol J 13(1):69-97

Fisher AT, Davis EE, Becker K (2008) Borehole-to-borehole hydrologic response across $2.4 \mathrm{~km}$ in the upper oceanic crust: implications for crustal-scale properties. J Geophys Res 113(B7):3109

Fisher AT, Davis EE, Hutnak M, Spiess V, Zühlsdorff L, Cherkaoul A, Christiansen K, Edwards K, Macdonald R, Villinger H, Mottl MJ, Wheat CG, Becker K (2003) Hydrothermal recharge and discharge across $50 \mathrm{~km}$ guided by seamounts on a young ridge flank. Nature 421(6923):618-621

Fisher AT, Wheat CG (2010) Seamounts as conduits for massive fluid, heat, and solute fluxes on ridge flanks. Oceanog 23(01):74-87

Gottlieb S, Shu C-W, Tadmor E (2001) Strong stability-preserving high-order time discretization methods. SIAM Rev 43(1):89-112

Griffith EM, Paytan A, Eisenhauer A, Bullen TD, Thomas E (2011) Seawater calcium isotope ratios across the Eocene-Oligocene transition. Geol Soc Am 39(7):683-686

Gussone N, Eisenhauer A, Heuser A, Dietzel M, Bock B, Böhm F, Spero HJ, Lea DW, Bijma J, Nägler TF (2003) Model for kinetic effects on calcium isotope fractionation $(844 \mathrm{Ca})$ in inorganic aragonite and cultured planktonic foraminifera. Geochim Cosmochim Acta 67(7):1375-1382

Gussone N, Heuser A (2016) Biominerals and biomaterial. In: Gussone N, Schmitt A-D, Heuser A, Wombacher F, Dietzel M, Tipper E, Schiller M (eds) Calcium stable isotope geochemistry. Springer, Berlin, pp 111-144

Gussone N, Nehrke G, Teichert BMA (2011) Calcium isotope fractionation in ikaite and vaterite. Chem Geol 285(1-4):194-202

Gussone N, Austrheim H, Westhues A, Mezger K (2020) Origin of rodingite forming fluids constrained by calcium and strontium isotope rations on the Leka Ophiolite Complex. Chemical Geology 542:119598

Heuser A, Eisenhauer A, Böhm F, Wallmann K, Gussone N, Pearson PN, Nägler TF, Dullo W-C (2005) Calcium isotope ( $\delta$ 44/40 Ca) variations of Neogene planktonic foraminifera. Paleoceanography 20(2): $1-13$

Heuser A, Eisenhauer A, Gussone N, Bock B, Hansen BT, Nägler TF (2002) Measurement of calcium isotopes using a multicollector TIMS technique. Int J Mass Spectrom 220(3):385-397

Heuser A, Schmitt A-D, Gussone N, Wombacher F (2016) Analytical methods. In: Gussone N, Schmitt A-D, Heuser A, Wombacher F, Dietzel M, Tipper E, Schiller M (eds) Calcium stable isotope geochemistry. Springer, Berlin, pp 23-74

Higgins JA, Schrag DP (2012) Records of Neogene seawater chemistry and diagenesis in deep-sea carbonate sediments and pore fluids. Earth Planet Sci Lett 357-358:386-396

Higgins JA, Blättler CL, Lundstrom EA, Santiago-Ramos DP, Akhtar AA, Ahm A-SC, Bialik O, Holmden C, Bradbury H, Murray ST, Swart PK (2018) Mineralogy, early marine diagenesis, and the chemistry of shallow-water carbonate sediments. Geochim Cosmochim Acta 220:512-534

Kuhn T, Versteegh GJM, Villinger H, Dohrmann I, Heller C, Koschinsky A, Kaul N, Ritter S, Wegorzewski AV, Kasten S (2017) 
Widespread seawater circulation in 18-22 Ma oceanic crust: impact on heat flow and sediment geochemistry. Geol

Langseth MG, Herman BM (1981) Heat transfer in the oceanic crust of the Brazil Basin. J Geophys Res 86(B11):10805-10819

Lemarchand D, Wasserburg GJ, Papanastassiou DA (2004) Rate-controlled calcium isotope fractionation in synthetic calcite. Geochim Cosmochim Acta 68(22):4665-4678

Magna T, Gussone N, Mezger K (2015) The calcium isotope systematics of Mars. Earth Planet Sci Lett 43:86-94

Marriott CS, Henderson GM, Belshaw NS, Tudhope AW (2004) Temperature dependence of $\delta 7 \mathrm{Li}, \delta 44 \mathrm{Ca}$ and $\mathrm{Li} / \mathrm{Ca}$ during growth of calcium carbonate. Earth Planet Sci Lett 222(2):615-624

McArthur JM, Howarth RJ, Bailey TR (2001) Strontium isotope stratigraphy: LOWESS version 3: best fit to the marine Sr-isotope curve for 0-509 Ma and accompanying look-up table for deriving numerical age. J Geol 109(2):155-170

Nielsen LC, Druhan JL, Yang W, Brown ST, DePaolo DJ (2012) Calcium isotopes as tracers of biogeochemical processes. In: Baskaran M (ed) Handbook of environmental isotope geochemistry. Springer, Berlin, pp 105-124

Ockert C, Gussone N, Kaufhold S, Teichert BMA (2013) Isotope fractionation during $\mathrm{Ca}$ exchange on clay minerals in a marine environment. Geochim Cosmochim Acta 112:374-388

Pabich S, Gussone N, Rabe K, Vollmer C, Pälike H, Teichert BMA (2014) Modelling changes of the Paleogene Ca budget using benthic foraminifera. Abstract PP51B-1127, in: AGU Fall Meeting, San Francisco. 15-19. Dec

Pälike H, Lyle M, Nishi H, Raffi I, Gamage K, Klaus A (Eds.) (2010) Proceedings of the IODP, 320/321. Integrated Ocean Drilling Program

Richter FM, DePaolo DJ (1987) Numerical models for diagenesis and the Neogene Sr isotopic evolution of seawater from DSDP Site 590B. Earth Planet Sci Lett 83(1-4):27-38

Richter FM, Liang Y (1993) The rate and consequences of Sr diagenesis in deep-sea carbonates. Earth Planet Sci Lett 117(3-4):553-565

Russel WA, Papanastassiou DA, Tombrello TA (1978) Ca isotope fractionation on the Earth and other solar system materials. Geochim Cosmochim Acta 42:1075-1090

Schulz HD (2000) Quantification of early diagenesis: dissolved constituents in marine pore water. In: Schulz HD, Zabel M (eds) Marine geochemistry. Springer-Verlag, Berlin, pp 85-128

Sime NG, De La Rocha CL, Tipper ET, Tripati A, Galy A, Bickle MJ (2007) Interpreting the $\mathrm{Ca}$ isotope record of marine biogenic carbonates. Geochim Cosmochim Acta 71(16):3979-3989
Skulan JL, DePaolo DJ, Owens (1997) Biological control of calcium isotopic abundances in the global calcium cycle. Geochim Cosmochim Acta 61(12):2505-2510

Spinelli GA, Giambalvo ER, Fisher AT (2004) Sediment permeability, distribution, and influence on fluxes in oceanic basement. In: Davis EE, Elderfield H (eds) Hydrogeology of the oceanic lithosphere. Cambridge Univ. Press, Cambridge, pp 151-188

Teichert BMA, Gussone N, Torres ME (2009) Controls on calcium isotope fractionation in sedimentary porewaters. Earth Planet Sci Lett 279(3-4):373-382

Teichert BMA, Torres ME, Bohrmann G, Eisenhauer A (2005) Fluid sources, fluid pathways and diagenetic reactions across an accretionary prism revealed by $\mathrm{Sr}$ and B geochemistry. Earth Planet Sci Lett 239(1-2):106-121

Turchyn AV, DePaolo DJ (2011) Calcium isotope evidence for suppression of carbonate dissolution in carbonate-bearing organic-rich sediments. Geochim Cosmochim Acta 75(22):7081-7098

Villinger H, Pichler T (2012) Effiziente Abkühlung junger ozeanischer Kruste durch Zirkulation von Meerwasser durch Seamounts (Guatemala Becken, Ostpazifik): Abschlußbericht für das Projekt SEAMOUNTFLUX. UBH, 1-106

Villinger HW, Pichler T, Kaul N, Stephan S, Pälike H, Stephan F (2017) Formation of hydrothermal pits and the role of seamounts in the Guatemala Basin (Equatorial East Pacific) from heat flow, seismic, and core studies. Geochem Geophys Geosyst 18(1):369-383

Voigt J, Hathorne EC, Frank M, Vollstaedt H, Eisenhauer A (2015) Variability of carbonate diagenesis in equatorial Pacific sediments deduced from radiogenic and stable Sr isotopes. Geochim Cosmochim Acta 148:360-377

Wheat CG, Mottl MJ, Rudnicki M (2002) Trace element and REE composition of a low-temperature ridge-flank hydrothermal spring. Geochim Cosmochim Acta 66(21):3693-3705

Wittke A, Gussone N, März C, Teichert BMA (2020) The effect of extraction techniques on $\mathrm{Ca}$ concentrations and isotope ratios of marine pore water. Isotopes in Health and Environment 56(1):51-68

Publisher's note Springer Nature remains neutral with regard to jurisdictional claims in published maps and institutional affiliations. 